\title{
GEM-AQ/EC, an on-line global multi-scale chemical weather modelling system: model development and evaluation of global aerosol climatology
}

\author{
S. L. Gong ${ }^{1,2}$, D. Lavoué ${ }^{1,3}$, T. L. Zhao ${ }^{1}$, P. Huang ${ }^{1}$, and J. W. Kaminski ${ }^{4}$ \\ ${ }^{1}$ Air Quality Research Division, Science \& Technology Branch, Environment Canada, 4905 Dufferin Street, Toronto, \\ Ontario M3H 5T4, Canada \\ ${ }^{2}$ Chinese Academy of Meteorological Sciences, China Meteorological Administration (CMA), Beijing 100081, China \\ ${ }^{3}$ DL Modeling \& Research, Brampton, Ontario, Canada \\ ${ }^{4}$ Department of Earth and Space Science and Engineering, York University, 4700 Keele Street, Toronto, \\ Ontario, M3J 1P3, Canada
}

Correspondence to: S. L. Gong (sunling.gong@ec.gc.ca)

Received: 1 December 2011 - Published in Atmos. Chem. Phys. Discuss.: 11 April 2012

Revised: 10 August 2012 - Accepted: 21 August 2012 - Published: 13 September 2012

\begin{abstract}
A global air quality modeling system GEM$\mathrm{AQ} / \mathrm{EC}$ was developed by implementing tropospheric chemistry and aerosol processes on-line into the Global Environmental Multiscale weather prediction model - GEM. Due to the multi-scale features of the GEM, the integrated model, GEM-AQ/EC, is able to investigate chemical weather at scales from global to urban domains. The current chemical mechanism is comprised of 50 gas-phase species, 116 chemical and 19 photolysis reactions, and is complemented by a sectional aerosol module CAM (The Canadian Aerosol Module) with 5 aerosols types: sulphate, black carbon, organic carbon, sea-salt and soil dust. Monthly emission inventories of black carbon and organic carbon from boreal and temperate vegetation fires were assembled using the most reliable areas burned datasets by countries, from statistical databases and derived from remote sensing products of 1995-2004. The model was run for ten years from from 1995-2004 with re-analyzed meteorology on a global uniform $1^{\circ} \times 1^{\circ}$ horizontal resolution domain and 28 hybrid levels extending up to $10 \mathrm{hPa}$. The simulating results were compared with various observations including surface network around the globe and satellite data. Regional features of global aerosols are reasonably captured including emission, surface concentrations and aerosol optical depth. For various types of aerosols, satisfactory correlations were achieved between modeled and observed with some degree of systematic bias possibly due
\end{abstract}

to large uncertainties in the emissions used in this study. A global distribution of natural aerosol contributions to the total aerosols is obtained and compared with observations.

\section{Introduction}

The potential impacts of aerosol particles on regional air quality and climate have been well recognized (IPCC, 2007; EPA, 1997). Aerosols, often referred to as particulate matter (PM) in air quality issues, are particles that are suspended in the atmosphere with size ranging from a few nanometres $(\mathrm{nm})$ to perhaps 100 micrometers $(\mu \mathrm{m})$ and produced from both natural and anthropogenic sources. PM has been a pollutant of concern in North America (NA) for nearly three decades. It is now realized that aerosols particles influence not only air quality but also meteorology like the way they are impacting the climate. The impact of global air pollution on climate and the environment is a new focus in the atmospheric science (Akimoto, 2003; Adhikary et al., 2010; Berntsen et al., 1996; Jacob and Winner, 2009). The air quality issue was regarded as a local problem only due to the emissions in a specific region. However, studies with models suggest large export of aerosols from source regions: about $70-80 \%$ by mass of most anthropogenic aerosol species is exported from Europe, Asia and North America; South and 
East Asia contribute about $15 \%$ of global sulphate and $30 \%$ of global black carbon (BC) pollution loads; Europe and North America each contribute about $5 \%$ of global BC and sulphate pollution loads (Koch et al., 2007). A recent assessment by the Task Force on Hemispheric Transport of Air Pollutants (TF HTAP) has found that anthropogenic emissions from one continent could contribute to the background levels of smog and PM in another continent (HTAP, 2010). The impact levels of smog and PM by the intercontinental transport varies depending the species and variability of the general circulation (Fiore et al., 2009; Reddy and Boucher, 2007; Liu et al., 2008).

Five major aerosol types are generally considered as the sources of particulate emissions in the atmosphere: sea salt (SS), mineral or soil dust (SD), black carbon (BC), particulate organic matter (POM), and sulfate (SU) (Textor et al., 2006). Aerosols affect directly and indirectly Earth's radiative balance. SS, SU, and POM tend to cool the atmosphere by reflecting light from the sun. SD scatters and partly absorbs solar radiation, depending on the particle size and chemical compositions. On the other hand, BC absorbs solar radiation and warms the atmosphere. The overall radiative impact of atmospheric aerosols is difficult to assess and is highly variable at regional scale (Penner et al., 2001; Kaufman et al., 2002). Recently, BC has been identified as an important contributor to radiative warming at global scale, and more particularly in the Arctic (Flanner et al., 2007). In addition, $\mathrm{BC}$ deposited on snow and ice reduces their albedo and can accelerate the melting. $\mathrm{BC}$ is currently the focus of many international studies to examine the effect of mitigating anthropogenic emission sources of the aerosol on both climate and air quality (Kandlikar et al., 2009; Jacobson, 2010; Baron et al., 2009; Governing Council of the United Nations Environment Programme, 2011).

The issue of the inter-annual variability in both natural aerosol emissions and intercontinental transport has not been fully addressed in previous aerosol modeling works. For instance, during the international AeroCom (Aerosol interComparison) experiment (Dentener et al., 2006) the aerosol emission inventories of both anthropogenic and natural origins for the year 2000 were collected from published inventories and simulations, in order to provide the harmonized global aerosol emission inputs to over 15 transport models. Similarly, the HTAP project aims to study the hemispheric and intercontinental transport of specific air pollutants including aerosols for the year 2001 only.

To adequately address this issue, the inter-annual variations in the emissions of various aerosols as well as in the transport patterns need to be addressed. The goal of the present study is two folds: (1) to develop a comprehensive emission inventory of natural aerosols for ten consecutive years from 1995 through 2004, and hence to investigate the inter-annual variability and seasonal cycle of SS, SD, BC, or POM emissions at continental and global scales, and (2) to evaluate the newly developed global air quality forecast model GEM-AQ/EC that uses the emissions.

Finally, a ten-year run using GEM-AQ/EC was performed to investigate global aerosol budgets and to capture the variability of the transboundary and intercontinental transport patterns. The ability of the model to simulate seasonal and inter-annual variations and regional distributions of the different aerosol components was validated with various surface station measurements and observations from satellites. Results from this study are presented in this paper and the companion paper published in the same journal issue (Zhao et al., 2012) focusing on the inter-annual variability of intercontinental transports of air pollutants and the meteorological influences.

\section{GEM-AQ/EC description}

Based upon the Canadian operational weather forecast model GEM (Global Environmental Mutilscale model) (Côté et al., 1998) and augmented by implementing tropospheric gas phase chemistry (Venkatram et al., 1988) and aerosols (Gong et al., 2003a), an on-line multiscale chemical weather modelling system GEM-AQ was developed to address the impact of aerosols and other pollutants on global air quality (Kaminski et al., 2008). The model GEM, as the host meteorological model for the on-line implementation of air quality processes could be run in global uniform, global variable and limited area configurations for modelling chemical weather at scales from global to urban domains. A full description of the model structure and evaluation of gas phase chemistry processes has been given by Kaminski et al. (2008). GEM-AQ is one of the models that contributed to the HTAP assessment. GEM-AQ/EC was enhanced from the original GEM-AQ model by adding more aerosol processes and new emissions as described below.

\subsection{Aerosol processes}

The aerosol processes in GEM-AQ/EC are simulated by the Canadian Aerosol Module (CAM) (Gong et al., 2003a), which is a size-segregated multicomponent aerosol module that includes aerosol microphysics, chemical transformation, aerosol-cloud interaction, and dry/wet depositions. The module accounts for five aerosol species: sea-salt, sulphate and soil dust, black carbon and organic carbon in 12 aerosol size (diameter) bins from 0.01 to $40.96 \mu \mathrm{m}$, and includes an explicit microphysical cloud module to treat aerosol-cloud interactions. In GEM-AQ/EC, the chemical mechanism module ADOM (the Acid Deposition and Oxidants Model, Venkatram et al., 1988) is used to model the gas chemistry, which interacts with the aerosol module. The aerosol module also implements the chemical transformation of sulphate and production of secondary aerosols, i.e. airborne aerosol mass produced by chemical transformation 
from their precursors together with particle nucleation, condensation and coagulation. These precursors are linked online with a gas phase chemistry module within the GEM-AQ (Kaminski et al., 2008) with emissions of active VOCs, such as isoprene and monoterpene in modeling aerosols (Kaminski et al., 2008).

An aerosol optical module is developed based on the Mie theory with pre-calculated scattering and absorbing coefficients. Dynamically coupled to the size segregated aerosol concentrations, the aerosol optical depth (AOD) of the five types of aerosols in GEM-AQ/EC is computed to enable the computation of the spatiotemporal distribution of aerosol optical characteristics, assessing model performance against observations, and interactively modeling the aerosol direct radiative effects (Ayash et al., 2008).

\subsection{Natural aerosol emissions}

The natural aerosols included in GEM-AQ/EC are sea salt produced from open oceans (Gong, 2003) and soil dust emitted from deserts (Marticorena and Bergametti, 1995; Fécan et al., 1999; Gong et al., 2003b). The sea salt and soil dust emissions are on-line calculated from the simulated meteorology in the GEM. The other natural emissions are carbonaceous aerosol emissions from boreal and temperate vegetation fires.

A Geographic Information System (GIS) application was developed to construct multi-year emission inventories for $\mathrm{BC}$ and POM from boreal and temperate vegetation fires. Vegetation fire emissions were calculated from the product of three components: vegetation fuel consumption values, emission factors, and areas burned data (Seiler and Crutzen, 1980). Fuel consumption and emission factors were previously described in (Lavoué et al., 2000). At a given location, the fuel consumption was set to be constant for the whole study period in all regions, except in Canada. Monthly area burned datasets were created using a composite approach combining fire statistics reported by countries and fire hotspots and scars detected by satellite. Vectorized polygons of burn scars available in some regions were converted into areas burned per grid cell. Next, monthly seasonality was inferred from official fire reports. However, if this information was not available, seasonal variability was introduced by scaling the emissions with MODIS (Moderate Resolution Imaging Spectroradiometer) Active Fires (USDA Forest Service, http://activefiremaps.fs.fed.us/) and ATSR (Along Track Scanning Radiometer) World Fire Atlas (European Space Agency, http://due.esrin.esa.int/wfa/) products. Both spacebased sensors provide fire hotspot counts, which can be used as proxy data for assessing fire activity on a monthly basis. This method was detailed and validated in earlier studies (Generoso et al., 2003; Schultz, 2002). It is worthwhile noticing that no satellite hotspot was used to derive annual areas burned in the present study. Also, as pointed out in earlier biomass burning studies (Schultz, 2002), examining fire statistical databases is a very time consuming and laborious but offers the advantage of limiting greatly the uncertainties on the areas burned. Table 1 lists the references in the literature and the web sites relative to areas burned statistics by geographical areas. More details for the treatment of each specific region can be found in Appendix A.

\subsection{Anthropogenic aerosol emissions}

Available monthly BC/POM emission inventories from anthropogenic biomass burning during 1995-2004 were limited at the start of the present study (mid-2000s). Emissions from Liousse et al. (1996) based on 1991 Food and Agriculture Organization production data for tropical forest fires, savannah fires, and biofuel burning were then set to be constant for the ten years of simulations with GEM-AQ/EC. Climatological emissions representative of the end of 1980's were considered for the tropical forest fires and savannah fires (Liousse et al., 1996). The vast majority of these fires are intentionally set fires for land conversion, timber harvesting, slashand-burn agriculture, and other socio-economic reasons. Biofuel burning adds up to a large contribution to the global emissions of carbonaceous particles. Sources include agricultural waste burning, residential cooking worldwide, burning of charcoal and dung, and charcoal making. A distinct seasonality to the emissions was applied accordingly to the hemisphere where they occur. The original $4.4^{\circ} \times 7.5^{\circ}$ inventory was interpolated onto a $1^{\circ} \times 1^{\circ}$ grid and a land-sea mask was applied to constrain emission fluxes to the land surface only.

Global emissions for BC and POM from fossil fuel combustion (Table 2) were calculated by applying the method developed by Cooke et al. (1999) and the United Nations fuel database (United Nations, 2007) for the years 1990-2005. This database provides consumption and transaction figures of 23 different fuel types (e.g. hard coal, lignite brown, diesel...) on an annual basis for more than 200 countries worldwide. For every country, a specific emission factor was applied to each fuel type consumed. Their values account for the level of development reached by the country. Emission factors are the same as the ones proposed initially by Cooke et al. (1999). BC emission inventories constructed with this technique were previously used to investigate transport pathways to the Arctic (Sharma et al., 2004) and to determine the relative contributions of circumpolar continental sources to the winter/spring Arctic Haze phenomenon (Gong et al., 2010).

The global sulphur emissions, including $\mathrm{SO}_{2}$, DMS and particulate sulphate, are based on the data of Global Emissions Inventory Activity (GEIA). For the GEM-AQ/EC simulations, the version $1 \mathrm{~A}$ of the GEIA inventory was used based on year 1985 . 
Table 1. Literature references and web sites visited to get areas burned by countries in different geographical areas between 1995 and 2004.

\begin{tabular}{|c|c|}
\hline Geographical areas & Literature references and web sites for areas burned (1995-2004) \\
\hline Canada & Stocks et al., (2003), http://cwfis.cfs.nrcan.gc.ca/en_CA/lfdb, Lavoué and Stocks (2011) \\
\hline Contiguous United States & http://iys.cidi.org/wildfire/firearch.htm \\
\hline Alaska & http://agdc.usgs.gov/data/blm/fire/ \\
\hline Mexico & http://www.conafor.gob.mx/portal/index.php/temas-forestales/incendios \\
\hline Eastern Europe & $\begin{array}{l}\text { European Commission (2005, 2006); UN/ECE Timber Bulletin (2002) } \\
\text { Bulgaria, Hungary, Poland, Czech Republic, Romania, Slovakia }\end{array}$ \\
\hline Northern Europe & $\begin{array}{l}\text { European Commission (2005, 2006); UN/ECE Timber Bulletin (2002) } \\
\text { Denmark, Estonia (Terep, 2004), Finland, Ireland, Latvia, Lithuania (Peleckas, 2004), Norway, } \\
\text { Sweden, United Kingdom }\end{array}$ \\
\hline Southern Europe & $\begin{array}{l}\text { European Commission (2005, 2006); UN/ECE Timber Bulletin, } 2002 \\
\text { Austria, Belgium, France (http://www.promethee.com), Germany (http://www.fire.uni-freiburg. } \\
\text { de), Luxembourg,Netherlands, Switzerland }\end{array}$ \\
\hline Western Europe & $\begin{array}{l}\text { European Commission (2005, 2006); UN/ECE Timber Bulletin (2002) } \\
\text { Austria, Belgium, France (http://www.promethee.com), Germany (http://www.fire.uni-freiburg. } \\
\text { de), Luxembourg, Netherlands, Switzerland }\end{array}$ \\
\hline Middle East & $\begin{array}{l}\text { European Commission (2005, 2006) } \\
\text { Cyprus, Israel, Lebanon (Bassil, 2000), Turkey (http://www.ogm.gov.tr/) ,Bilgili (1997) }\end{array}$ \\
\hline North Africa & $\begin{array}{l}\text { Algeria (Madoui, 2002), Libya (ECE/FAO Agriculture and Timber Division, 1986), Morocco } \\
\text { (Forestry Department/FAO, 2001), Tunisia (ECE/FAO Agriculture and Timber Division, 1986) }\end{array}$ \\
\hline Russia & $\begin{array}{l}\text { Sukhinin et al. (2004a, b), (http://www.landcover.org/data/burned/, } \\
\text { http://www.fire.uni-freiburg.de/) }\end{array}$ \\
\hline Mongolia & Erdenesaikhan and Erdenetuya (1999); Valendik et al. (1998) \\
\hline
\end{tabular}

Table 2. Annual aerosol emissions by source types in the Northern and Southern Hemispheres, and globally over the $10 \mathrm{yr}(\mathrm{SS}=\mathrm{sea}$ salt, $\mathrm{SD}=$ soil dust, $\mathrm{BC}=$ black carbon, $\mathrm{POM}=$ particulate organic matter).

\begin{tabular}{|c|c|c|c|c|c|c|c|c|}
\hline & \multirow{2}{*}{$\begin{array}{l}\text { Open ocean } \\
\text { SS } \\
\left(10^{12} \mathrm{~kg} \mathrm{yr}^{-1}\right)\end{array}$} & \multirow{2}{*}{$\begin{array}{l}\begin{array}{l}\text { Deserts and } \\
\text { semi-deserts }\end{array} \\
\text { SD } \\
\left(10^{11} \mathrm{~kg} \mathrm{yr}^{-1}\right)\end{array}$} & \multicolumn{2}{|c|}{ Boreal and temperate vegeration fires } & \multicolumn{2}{|c|}{ Global fossil fuel burning } & \multicolumn{2}{|c|}{$\begin{array}{l}\text { Tropical forest and savanna fires } \\
\text { Global crop and biofuel fires }\end{array}$} \\
\hline & & & $\begin{array}{l}\mathrm{BC} \\
\left(10^{7} \mathrm{~kg} \mathrm{yr}^{-1}\right)\end{array}$ & $\begin{array}{l}\text { POM } \\
\left(10^{9} \mathrm{~kg} \mathrm{yr}^{-1}\right)\end{array}$ & $\begin{array}{l}\text { BC } \\
\left(10^{8} \mathrm{~kg} \mathrm{yr}^{-1}\right)\end{array}$ & $\begin{array}{l}\text { POM } \\
\left(10^{8} \mathrm{~kg} \mathrm{yr}^{-1}\right)\end{array}$ & $\begin{array}{l}\text { BC } \\
\left(10^{9} \mathrm{~kg} \mathrm{yr}^{-1}\right)\end{array}$ & $\begin{array}{l}\text { POM } \\
\left(10^{10} \mathrm{~kg} \mathrm{yr}^{-1}\right)\end{array}$ \\
\hline NH & $6.9 \pm 0.2(33 \%)$ & $19.9 \pm 1.2(94 \%)$ & $21.4 \pm 6.4$ & $3.6 \pm 1.3$ & $65.8 \pm 6.1(90 \%)$ & $91.4 \pm 6.4(93 \%)$ & $2.9(52 \%)$ & $2.8(52 \%)$ \\
\hline $\mathrm{SH}$ & $13.7 \pm 0.3(67 \%)$ & $1.3 \pm 0.6(6 \%)$ & $\mathrm{n} / \mathrm{a}$ & $\mathrm{n} / \mathrm{a}$ & $7.2 \pm 0.8(10 \%)$ & $7.0 \pm 0.8(7 \%)$ & $2.7(48 \%)$ & $2.6(48 \%)$ \\
\hline Global & $20.6 \pm 0.3$ & $21.2 \pm 1.4$ & $21.4 \pm 6.4$ & $3.6 \pm 1.3$ & $73.0 \pm 6.7$ & $98.4 \pm 6.8$ & 5.6 & 5.4 \\
\hline
\end{tabular}

\subsection{Simulation setup}

The GEM-AQ/EC used in the study was configured with 28 hybrid vertical levels with the model top at $10 \mathrm{hPa}$. The horizontal model grid was configured as global uniform resolution of $1^{\circ} \times 1^{\circ}$. The GEM-AQ/EC was run with the fully nudged variables of wind, temperature, pressure and water vapor of NCEP-reanalysis meteorology every $24 \mathrm{~h}$. This nudge setup resulted in the meteorological fields with 24-h forecast segments starting from the reanalysis meteorology with the meteorological simulation being forced to observations of the NCEP reanalysis meteorology. Initial aerosol conditions were generated by GEM-AQ/EC running with a three-month spin-up in the same global uniform configuration. The initial concentrations of gaseous chemistry are from the global distribution of October 1 averaged from the 5-yr GEM-AQ simulation (Kaminski et al., 2008). Therefore, a spin-up of 3 months starting on 1 October 1994 is enough for aerosols and also for gas-phase chemistry in the troposphere. The GEM-AQ/EC simulations were conducted over 10 consecutive years of 1995-2004 to generate a comprehensive "climatology" of global aerosol emission, concentration, column loading, dry and wet depositions as well as the regional, hemispheric and global transport patterns. In the simulations, the anthropogenic emissions have no inter-annual variability over 10-yr with variable emissions of natural sea-salt and 

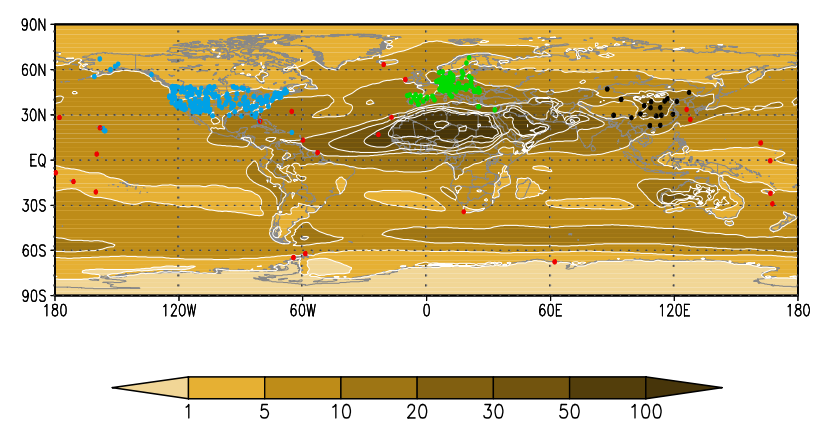

Fig. 1. Geographic locations of observational sites used in comparing with modeling results. The background contours are the $\mathrm{PM}_{10}$ concentrations $\left(\mu \mathrm{g} \mathrm{m}^{-3}\right)$ averaged from the ten years of modelled results. Blue dots are stations from IMPROVE and CAPMoN in North America, green dots are the stations from EMEP of Europe, black dots are stations from CAWNET of China and red dots are the stations from GAW and Miami University research stations.

soil dust aerosols calculated on-line from the modelled meteorology and other surface parameters as well as the natural components of $\mathrm{BC}$ and POM. This configuration allows the assessments of the impact of meteorology on the global distribution and transport of air pollutants as well as the contribution of natural aerosols to the global air quality.

\section{Global aerosol distributions}

In order to evaluate the performance of GEM-AQ/EC for simulating global aerosols at various regions, observational data from a number of long term monitoring networks are selected, including IMPROVE (Interagency Monitoring of Protected Visual Environments) and CAPMoN (Canadian Air and Precipitation Monitoring Network) from North America, EMEP (European Monitoring and Evaluation Program) from Europe and CAWNET (China Atmosphere Watch Network) from China. AOD data from AeroNet, aerosol data from GAW (Global Atmospheric Watch) stations as well as data from Miami University research stations are also used. Figure 1 shows the geographic distributions of the surface observational networks used to compare with the modeling results. In addition, satellite observation of AOD by MODIS is also used in this study.

\subsection{Global emissions of natural aerosols}

In the following, the aerosol emissions inventories were calculated with the methods described in Sect. 2.2. Annual estimates are compared to inventories available in the literature. Table 2 summarizes the natural aerosol emissions of sea-salt, soil dust and carbonaceous aerosols into various categories and hemispheres.

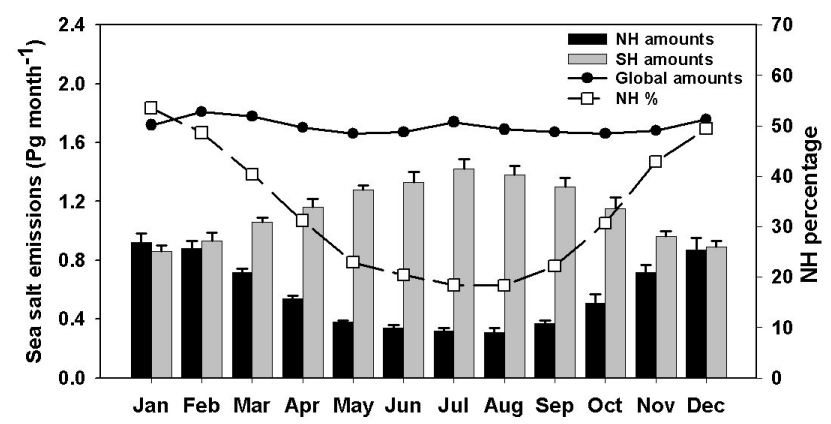

Fig. 2. Seasonality of sea salt aerosol mass production (mean \pm s.d.) at global scale and in the Northern $(\mathrm{NH})$ and Southern Hemisphere $(\mathrm{SH})$ oceans $\left(1 \mathrm{Pg}=10^{12} \mathrm{~kg}\right)$.

\subsubsection{Sea salt production from open oceans}

Figure 2 shows the global sea-salt emissions with a pronounced seasonality in both hemispheres. Monthly emissions in Southern Hemisphere $(\mathrm{SH})$ reach 1.4 Pg month ${ }^{-1}$ in July-August during the austral winter, whereas Northern Hemisphere (NH) maximum corresponds to $1.0 \mathrm{Pg}$ month $^{-1}$ in December-February during the boreal winter. About twothirds of the emissions are located in the SH and one-third in the NH (Table 2, Fig. 3a). The annual global SS mass production during the study period corresponds to $20.77 \times$ $10^{12} \mathrm{~kg} \mathrm{yr}^{-1}$. Table 2 presents total emissions by particle type at global scale and for Northern and Southern Hemispheres. SS is one the major contributors to the mass of particulate matter injected in the atmosphere. One order of magnitude separates global SS to SD amounts.

The annual estimate of $20.7 \times 10^{12} \mathrm{~kg}$ is in the upper range of the annual emission estimates from $0.3 \times 10^{12}$ to $30 \times$ $10^{12} \mathrm{~kg} \mathrm{yr}^{-1}$ found across the literature (Lewis and Schwartz, 2004). Gong et al. (1997b) determined a total of $11.7 \times$ $10^{12} \mathrm{~kg} \mathrm{yr}^{-1}$ based on the SS product flux formulation of Monahan et al. (1986) and using wind speed observations at several locations around the globe. Later, Gong et al. (1998) determined a much lower total of $3.33 \times 10^{12} \mathrm{~kg} \mathrm{yr}^{-1}$ applying the same mathematical formula to wind fields calculated with a global transport model (Gong et al., 2002). Chin et al. (2002) followed a similar approach with a global transport model and calculated the annual emissions of 5.8$7.5 \times 10^{12} \mathrm{~kg}$. Schulz et al. (2004) determined $19.8 \times 10^{12} \mathrm{~kg}$. Grini et al. (2002) determined a total of $6.5 \times 10^{12} \mathrm{~kg} \mathrm{yr}^{-1}$ based on global transport model using Monahan et al. (1986) for the radius at $80 \%$ relative humidity, i.e. $r_{80}<7 \mu \mathrm{m}$ and O'Dowd and Smith (1993) for $r_{80}>7 \mu \mathrm{m}$. For the AeroCom experiment, daily SS emission rates were based on year 2000 ECMWF near surface winds and totalized $7.93 \times 10^{12} \mathrm{~kg}$ (Dentener et al., 2006). 

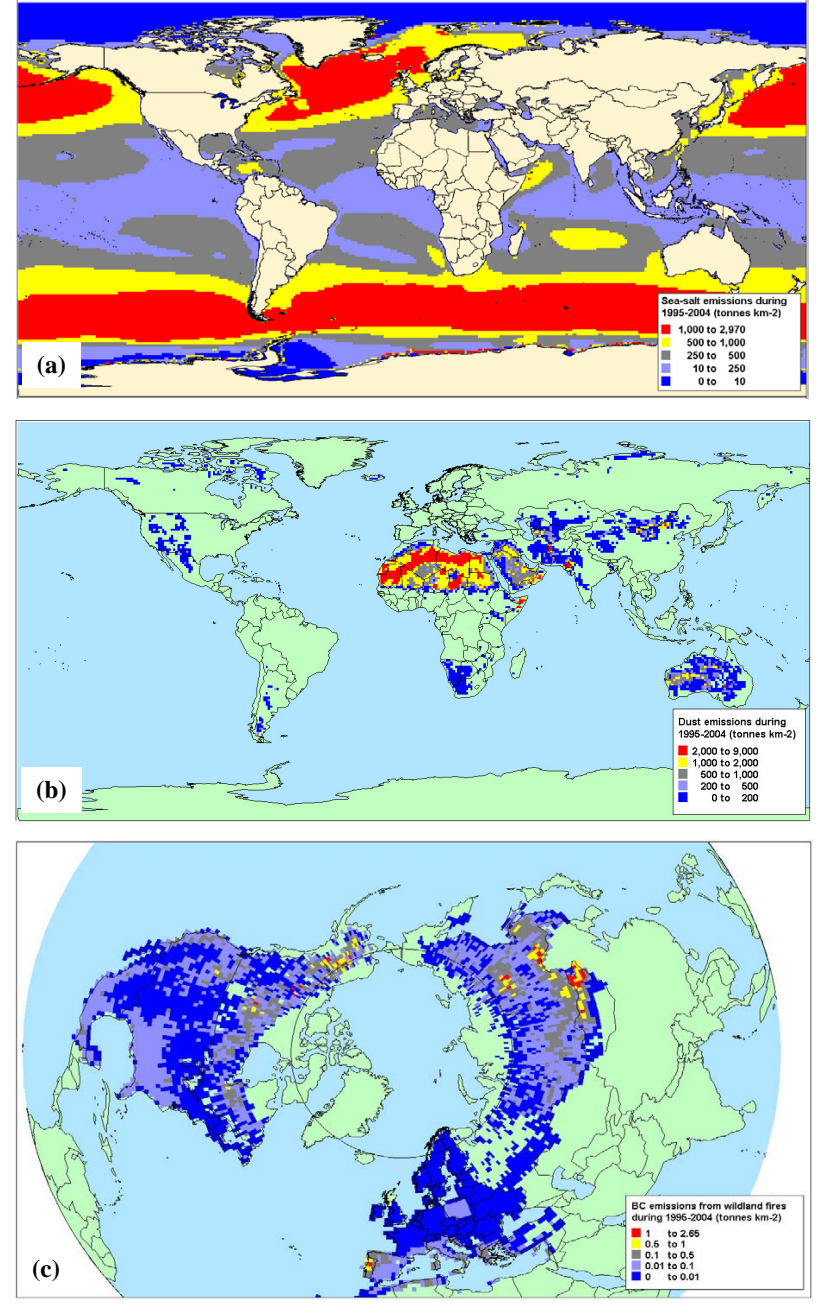

Fig. 3. Total emission maps of global sea-salt (a), global mineral dust (b), BC from boreal and temperate vegetation fires (c) in metric tonnes per $\mathrm{km}^{2}$ during 1995-2004.

\subsubsection{Soil dust emission from desert areas}

During 1995-2004, the range of global SD emissions calculated with the CAM dust scheme is $1880-2330 \mathrm{Tg} \mathrm{yr}^{-1}$, which is comparable to previous estimates of 1000 to 2150

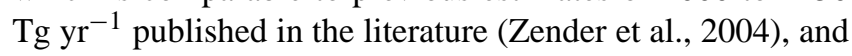
the maximum is calculated for 2002 with $2330 \mathrm{Tg}$ of dust emitted to the atmosphere. The averaged global emission of $2120 \pm 140 \mathrm{Tg} \mathrm{yr}^{-1}$ is comparable to the global mean of $2073 \mathrm{Tg} \mathrm{yr}^{-1}$ calculated between 1981 and 1996 by Ginoux et al. (2004). Among 15 global aerosol models within the AeroCom project, there were large differences in simulating the dust cycle and its impact on climate (Huneeus et al., 2011).

Figure $3 b$ presents the spatial distribution of total SD emissions in tonnes $\mathrm{km}^{-2}$ for the $10 \mathrm{yr}$ of this study. This figure clearly points out the large emissions occurring in the two prominent desert areas of North Africa and East Asia. Fig- ure 4 exhibits the "roller-coaster" type-monthly variation of dust emissions at global scale and for the major deserts. The largest sources of dust are located in North Africa and are roughly larger by one order of magnitude than that of Asia. More than three-quarters of global dust emissions occur in North Africa.

Dust emissions from Saharan desert occur all year long with a minimum in the wintertime and a maximum during the summer (Fig. 4). The modeling outputs suggest that average emissions are $1600 \pm 130 \mathrm{Tg} \mathrm{yr}^{-1}$ with a maximum of 1750 $\mathrm{Tg}$ in 2002. Kaufman et al. (2005a) estimated that $240 \pm 80$ $\mathrm{Tg}$ of African dust are transported to the Atlantic Ocean every year by using MODIS satellite imagery. Recent studies pointed out that localized sources are responsible for most of the North African SD emissions. The Bodélé region (15$20^{\circ} \mathrm{E}, 12-18^{\circ} \mathrm{N}$ ) is considered as the most active source of dust in the Sahara desert, and probably in the world (Koren et al., 2006; Washington and Todd, 2005; Tegen et al., 2006). The Bodélé is an enclosed topographic depression located between the Tibesti Mountains and Lake Chad. High velocity winds are associated to the particular topography of the area. Field observations pointed out that the ground is made of very fine remains of microscopic freshwater organisms, which populated the lake Mega-Chad thousands years ago, whereas the soil of northern Sahara is mostly composed of a mixture of clay aggregates. Ginoux et al. (2004) estimated that the Bodélé is responsible for up to half of all the dust that leaves West Africa, and Todd et al. (2007) suggested that the region might release $1.2 \pm 0.5 \mathrm{Tg}$ of dust per day during substantial dust events. Prospero and Lamb (2003) claimed that dust emissions from the Sahara considerably increased in past decades. Results from this study spanning only $10 \mathrm{yr}$ are not able to confirm their conclusion.

Dust emissions from East Asia have a more pronounced seasonality than those in North Africa. Dust events originate every spring from the Gobi desert $\left(36-44^{\circ} \mathrm{N}, 100\right.$ $\left.114^{\circ} \mathrm{E}\right)$, located in southern Mongolia and northern China. Dust episodically degrades the air quality and reduces visibility in urban areas, as far as Beijing, during March-April. Giant Asian dust clouds are carried eastward affecting atmosphere over Korean and Japan (Kim et al., 2010), sometimes crossing the North Pacific to reach western North America (Zhao et al., 2008). Figure 4 indicates the great yearto-year variability in SD emissions from Asian deserts with 2001, 1995, 1998, and 2000 as high emission years in order of decreasing amounts. On average, emissions represent $52 \pm 19 \mathrm{Tg} \mathrm{yr}^{-1}$ between 1995-2004, with a maximum of 89 $\mathrm{Tg}$ during 2001. In that year, the spring dust season was characterized by four major observed sand storm episodes, which lasted about one month in total (Gong et al., 2003b). These events were the subject of many modeling studies, field experiments, and remote sensing observations (Zhao et al., 2006; Gong et al., 2006). Contrary to dust emissions from the Sahara desert, dust emissions from Asian desert are very limited outside the spring window (Fig. 4). 


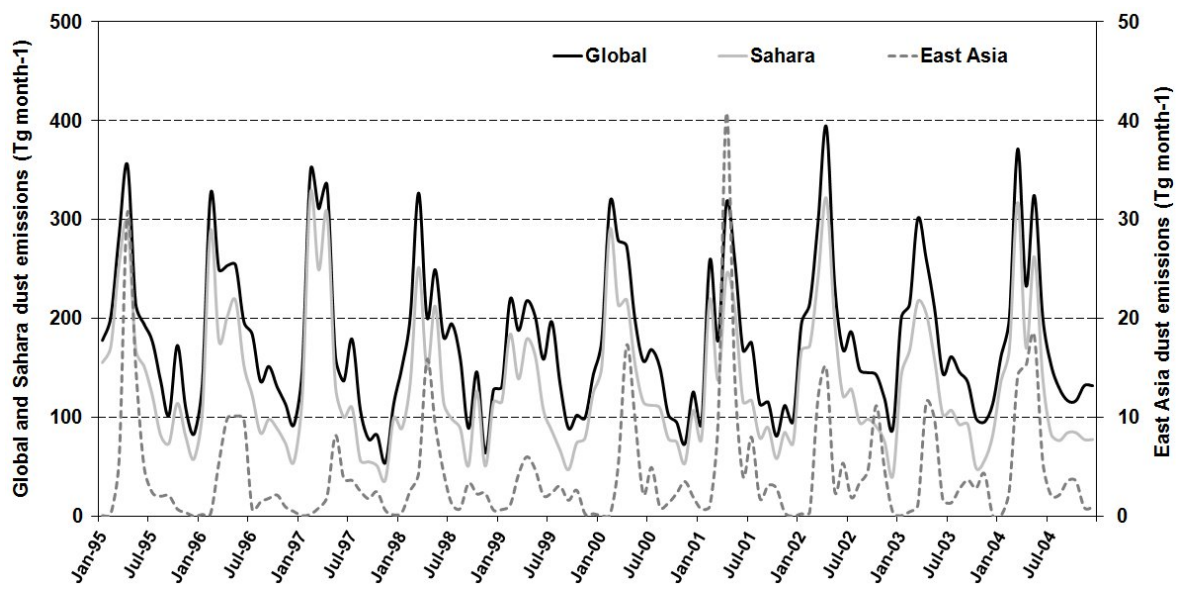

Fig. 4. Monthly emissions of mineral dust from global deserts and for the Sahara and East Asia desertic areas from 1995 through 2004.

Finally, SD emissions from North American deserts are relatively much lower compared to those occurring in the Sahara and Gobi deserts. They correspond on average to $4 \pm 2 \mathrm{Tg} \mathrm{yr}^{-1}$, which contribute only to $0.2 \%$ of the global $\mathrm{SD}$ emissions. Over the $10 \mathrm{yr}$ of the study, a maximum of 8 Tg was reached in 1998. Modeling outputs suggest that the 2001 "Red Bowl" dust episode in southern US represented "only" 3 Tg (Park et al., 2007).

\subsubsection{Black carbon from boreal and temperate vegetation fires}

Figure 5a shows the high inter-annual variability of black carbon emissions from vegetation fires in Canada, Alaska, conterminous US, Russia, Mongolia, and all other geographical areas combined. Russian contribution is preponderant due to its large forest territory and nature of fires occurring with alltime high in 2003. Large emissions in 2002 and 2003 were due to extreme fire events in both North America and Siberia. There is a factor 2 to 3 between the minimum in 2001 and the maximum in 2003 for total BC emissions. Southern Europe is the predominant source region of natural $\mathrm{BC}$ west of the Ural Mountains. In particular, the 2003 fires in Southern Europe were a large source of emissions. On average, Russia and Canada represents $36 \%$ and $19 \%$ of BC emissions. Conterminous US accounts for almost $10 \%$ of total emissions with the largest contribution located in the western part of the country.

Table 3 compares the annual BC estimates to the Global Fire Emissions Database (GFED) v2.1 for countries which are estimated to have the largest emissions (van der Werf et al., 2006). Mean and standard deviation values are presented for 1995-2004, GFED time period 1997-2006, and the overlap period between the two datasets. GFED emissions are based on areas burned derived from MODIS hotspots (Giglio et al., 2006) and then do not include any statistical information from agencies' field reports. Standard deviations cal-
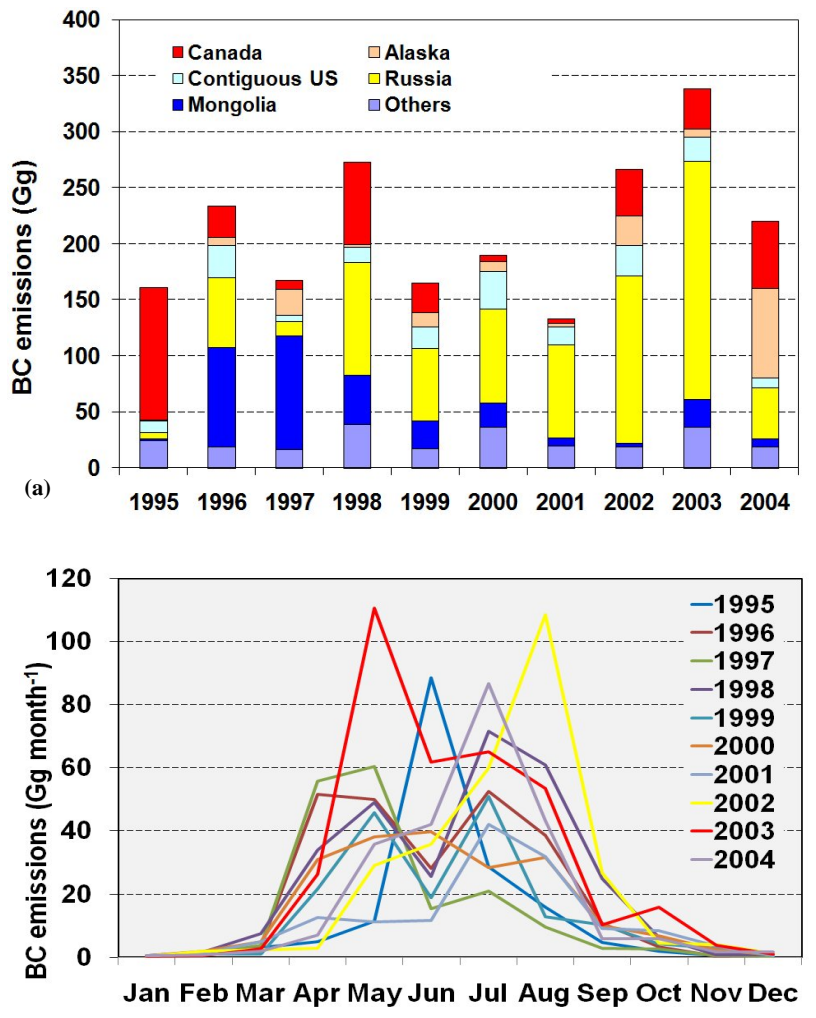

(b)

Fig. 5. Inter-annual (a) and monthly variability (b) of black carbon emitted by wildland fires in the boreal and temperate regions.

culated from both datasets are shown to be high, hence indicating great inter-annual variability of the emissions (Table 3). Both inventories agree that Russia and Canada are the main contributors to $\mathrm{BC}$ from vegetation fires in the Northern Hemisphere.

Figure $5 \mathrm{~b}$ illustrates the monthly variability of total $\mathrm{BC}$ emissions from vegetation fires at boreal and temperate 
Table 3. Comparison of BC emissions from vegetation fires to Global Fire Emission Database version 2.1 for countries with the largest emissions in the boreal and temperate regions (in $\mathrm{Gg}$ ).

\begin{tabular}{lrr|rr}
\hline & GFED v2.0 (van der Werf et al., 2006) & \multicolumn{2}{c}{ This study } \\
\cline { 2 - 5 } & $1997-2006$ & $1997-2004$ & $1995-2004$ & $1997-2004$ \\
\hline Canada & $42.9 \pm 32.5$ & $46.4 \pm 35.9$ & $40.3 \pm 35.6$ & $32.1 \pm 25.9$ \\
Alaska & $7.7 \pm 11.1$ & $6.4 \pm 10.2$ & $17.0 \pm 23.7$ & $20.3 \pm 25.6$ \\
Russia & $220.8 \pm 155.2$ & $243.1 \pm 166.6$ & $82.2 \pm 62.0$ & $94.2 \pm 62.4$ \\
Mongolia & $4.7 \pm 3.4$ & $5.3 \pm 3.5$ & $32.4 \pm 35.5$ & $29.2 \pm 32.0$ \\
Contiguous US & $20.3 \pm 6.8$ & $20.8 \pm 7.5$ & $18.5 \pm 9.2$ & $18.2 \pm 9.3$ \\
\hline
\end{tabular}

latitudes for each year. The seasonal cycle is clearly driven by the boreal fire activity that ceases during wintertime. Peak usually occurs during the summer months, except in 1996 with a maximum in May due to Mongolian fires. In that country, fire statistics and remote sensing indeed reveal that a large number of fires can occur during springtime, and spread quickly in the extensive steppe and stepped-forest areas. However, summertime monsoon rains seriously limit the number of fires.

The variability in the number of ATSR nighttime fire counts was employed as a proxy for determining the monthly variability in the area burned from annual AVHRR fire scars in Siberia. Generoso et al. (2003) pointed out that ATSR fire pixels show globally a seasonal cycle consistent with diverse satellite products used in fire detection, including daily TRMM (Tropical Rainfall Measuring Mission) products, daily AVHRR imageries, and satellite SPOT-derived Global Burnt Area 2000 mapping (Tansey et al., 2004).

\subsection{Comparisons with AOD by satellites}

Hemispheric-scale differences in land area $(39 \%$ of the Northern Hemisphere is covered by land vs. $19 \%$ in the Southern Hemisphere) and in human population have led to large inter-hemispheric differences in aerosol source strengths. This, in turn, leads to the difference in the global aerosol distributions (Textor et al., 2006). Satellite observation of aerosols by AOD has the advantage of displaying the main feature of global aerosol distributions and revealing the regional characteristics. Figure 6 shows the global AOD from satellite observations of monthly averaged MODIS over the period of 2000-2004 with the model simulated AOD as the sum of the single species contribution from sulphate, sea-salt, black carbon, organic carbon and soil dust aerosols for four seasons.

The main features of the global aerosol distributions are captured by the GEM-AQ/EC. Four regions in the globe, i.e. North America, Europe, South Asia and East Asia, have the majority of the global anthropogenic emissions and contribute to the regional and global aerosol burdens. This is clearly reflected in Fig. 6 where four aerosol plumes are ob- served and simulated with long range transports. The AODs predicted are comparable with the satellite observations.

The natural sources of aerosols are in the desert areas and over the oceans. The aerosol regime in Africa is a good example of a primary (soil dust) aerosol mixing with primary and secondary biomass burning aerosols. The soil dust component covers the Saharan desert source region and extends thousands of kilometres downwind. The tran-Atlantic transport of African dust aerosols was clearly visible from both observed and simulated AODs. This is also consistent with the emission patterns shown in Fig. 3 for dust aerosols.

There are seasonal variations observed and predicted, especially for the natural components. Dust aerosols show a distinct peak in East Asia spring and transports over the $\mathrm{Pa}$ cific. High summer AOD in central Africa that is linked to the bio-mass burning has been well simulated by the GEM$\mathrm{AQ} / \mathrm{EC}$.

\subsection{Comparisons with AOD by AERONET}

To further evaluate the model performance, monthly modeled AOD was compared with the surface based global AERONET AOD observations from 1995 to 2004. AERONET data cover the whole $10 \mathrm{yr}$ of simulation period. Simulated AODs were distributed in the horizontal model grid at the global uniform resolution of $1^{\circ} \times 1^{\circ}$ and mapped into the corresponding AERONET sites in order to be compared. No filter was applied to the AERONET station data to calculate monthly averages. The significance of correlation could be calculated, based on the t-test, to assess whether the means of both groups were statistically different from each other. Both groups of simulated and observed AODs were built from the same spatial and temporal distributions of AERONET sites during the $10 \mathrm{yr}$ of simulation. The correlation between the two groups is shown in Fig. 7 to evaluate the AOD modeling against the AERONET observations. Due to the difference in the number of stations from year to year, the significance levels of the correlation may vary slightly but the averaged correlation coefficient $(r)$ for the 10 yr reaches above 0.57 (Fig. 7). For each season, the percentages of under-estimates, within a factor of two and overestimates are shown and explained in the caption. It can be 

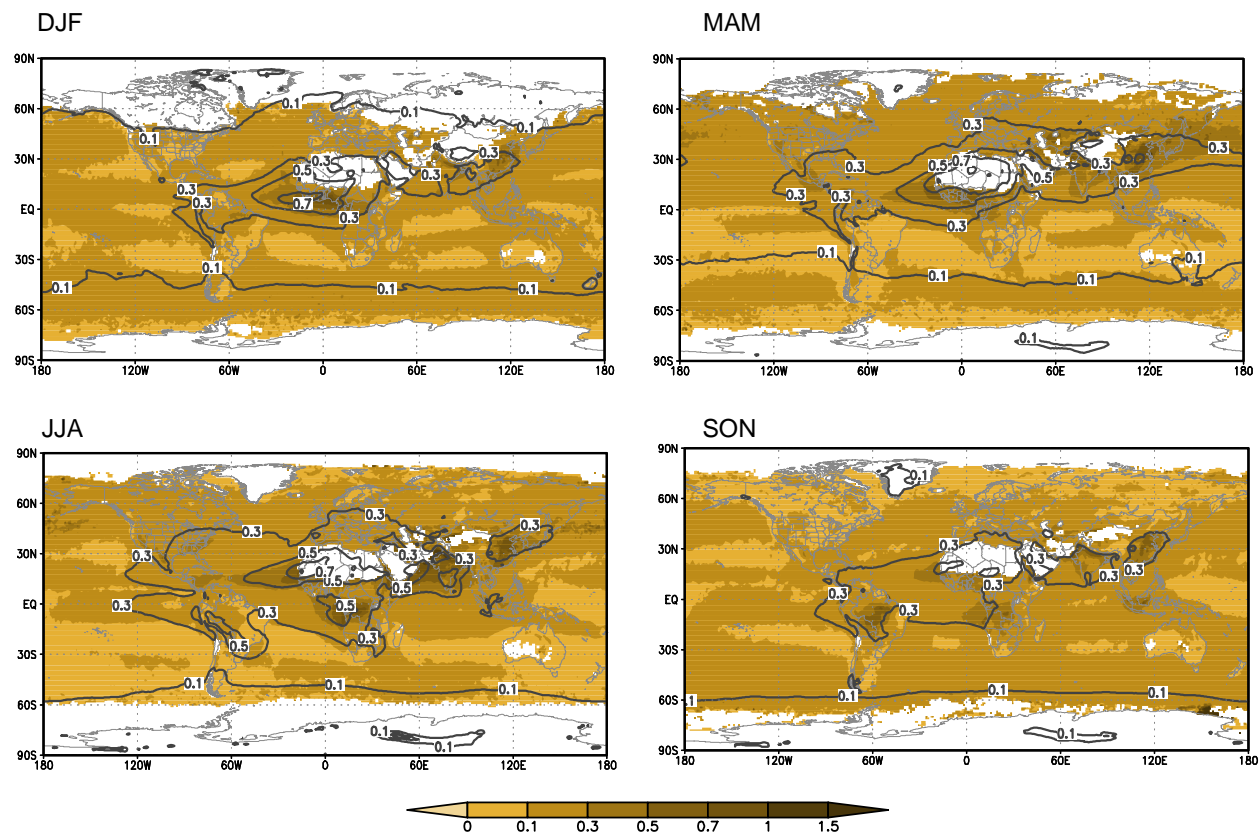

Fig. 6. Comparisons of seasonally averaged AOD between MODIS and model simulations for 2000-2004. The filled contours are for MODIS and the contour lines are for model simulations.

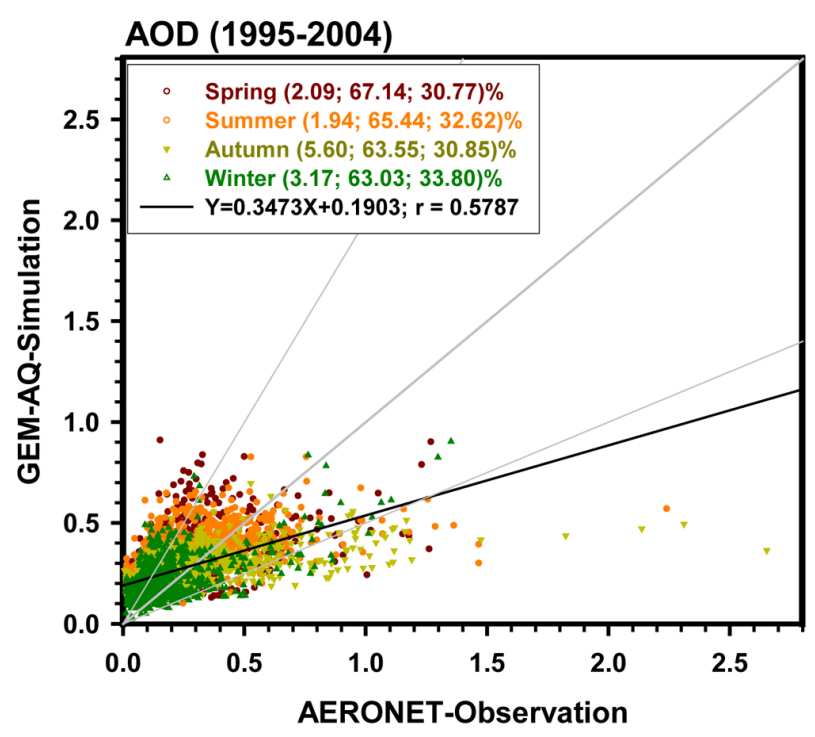

Fig. 7. Correlation between model-simulated AOD and AERONET observations from 1995 to 2004. Scattered dots are grouped into four seasons, each of which shows a different behavior. Dots within the gray area indicate the modeled AODs are within a factor of 2 from observations. The numbers in the bracket following the season are the percentages of modeled results with under-, within a factor of 2 and over-estimations.

seen from the figure that the model has captured the global spatial and temporal distributions of the AODs, which have been qualitatively illustrated by the comparison with satellite observations (Fig. 6). More than $63 \%$ of the simulated points are within a factor of two (shaded area in Fig. 7) compared with the observations. Overestimates for about $30-34 \%$ of the points are found for the lower AOD $(<0.3)$ and underestimate for about $2-6 \%$ of the points for higher AOD values $(>0.3)$. Seasonally, autumn sees the highest underestimate and winter the highest over-estimate. These differences could be caused by the seasonal changes of aerosol emissions and the aerosol transport driven by atmospheric circulations.

This comparison yields some insights into the model performance and emissions. The reasonable correlation coefficient indicates the acceptable skills of the model in predicting the spatial and temporal distributions of AOD around the globe. It is interesting to note that the over-estimates for $30-40 \%$ of the points are located in the lower AOD regions where more AERONET sites are stationed and lower emissions of PM are found, such as in the North America and Europe. Conversely, under-estimates are seen over much less points $(2-6 \%)$ in the AERONET sties and in the high AOD regions. This may point to the possibility of underestimates of emissions in the polluted areas, e.g. Asia, and over-estimates in the relatively less polluted regions, e.g. North America.

\subsection{Comparisons with surface observations}

Speciated PM observations are available from some surface monitoring stations such as IMPROVE and EMEP with $\mathrm{PM}_{10}$ and $\mathrm{PM}_{2.5}$ concentrations. The comparisons between observed and predicted PM concentrations are given 
(a)
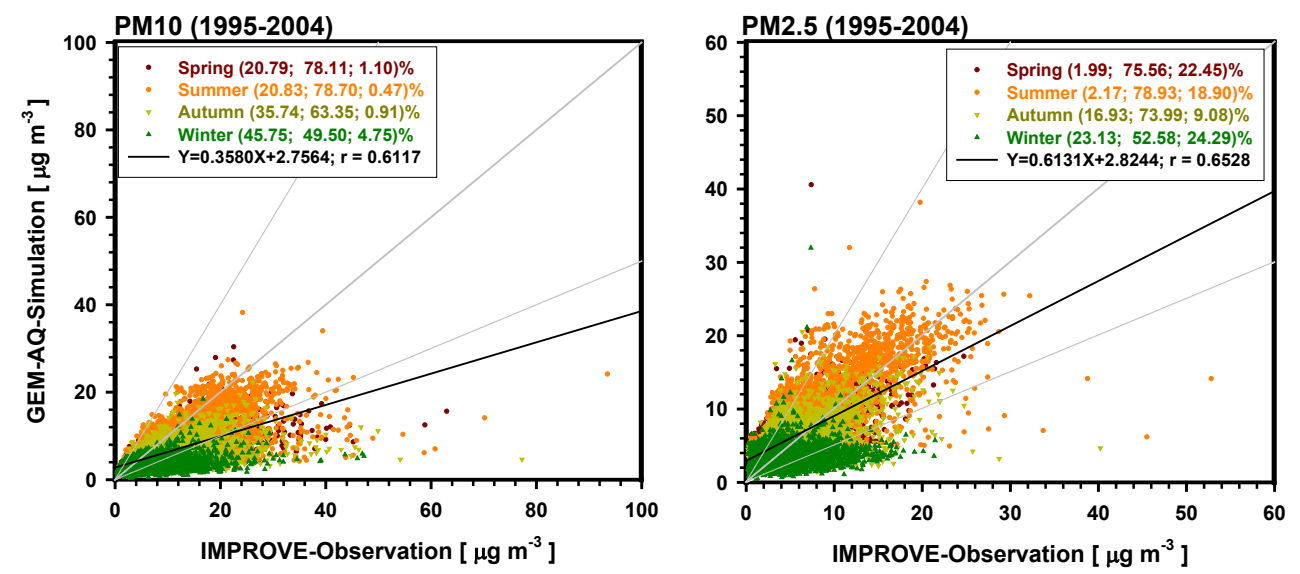

(b)
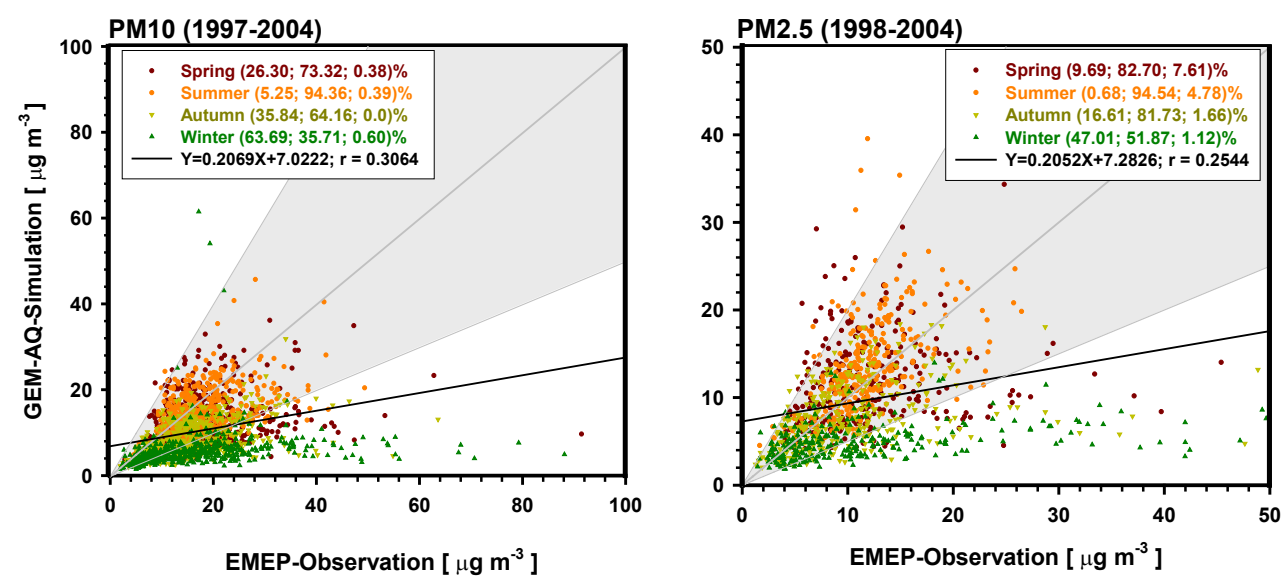

Fig. 8. Correlations of seasonally averaged $\mathrm{PM}_{10}$ and $\mathrm{PM}_{2.5}$ with network observations in (a) North America and (b) Europe. Legend explanations are given the same as in Fig. 7.

in Fig. 8a for North America and Fig. 8b in Europe. Reasonable comparisons are achieved for North America with correlation coefficients $(r)$ reaching 0.61 and 0.65 for the $10 \mathrm{yr}$ averaged $\mathrm{PM}_{10}$ and $\mathrm{PM}_{2.5}$, respectively. For $\mathrm{PM}_{10}$, the simulation results for spring and summer are more than $78 \%$ within a factor of two compared to observations with about $20 \%$ underestimates. The under-estimates increase to $35-45 \%$ in autumn and winter. It seems that certain sources of coarse particles are missed by the modeling system.

The model performance for Europe is not as good as for NA with correlation coefficients $(r)$ only reaching 0.31 and 0.25 for the averaged $\mathrm{PM}_{10}$ and $\mathrm{PM}_{2.5}$, respectively. It should be noted that the observational data for Europe has a slightly shorter time span than the NA data. Except for winter months when large under-estimates of the model predictions are found, most of the predictions are within a factor of two from the observations (Fig. 8b). For both NA and EU, the summer has the best performance.
To narrow down the causes for the bias of model predictions for PM in North America, the speciated aerosol concentrations of soil dust, sulphate, $\mathrm{BC}$ and $\mathrm{OC}$ were compared with observations by the IMPROVE network (Fig. 9). Model performance was evaluated by separating NA into west and east regions. For all the species, the modelled concentrations are correlated better with observed concentrations in the east NA than those in the west NA. The correlation coefficients $(r)$ for soil dust and sulphate aerosols are about 0.73 and 0.83 in the east NA, 0.50 and 0.46 in the west NA. The model performance is much lower for carbonaceous aerosols with correlation coefficients around 0.40 in the east and 0.30 in the west. There are no obvious reasons for the difference between the west and east NA but the accuracy in the emission inventory of anthropogenic sulphur and carbonaceous species may have played a role in this. The method of fire emission estimation seems unsatisfactory, when the model performance of $\mathrm{BC}$ and $\mathrm{OC}$ prediction is concerned. The method to calculate emissions from boreal fires, presented 


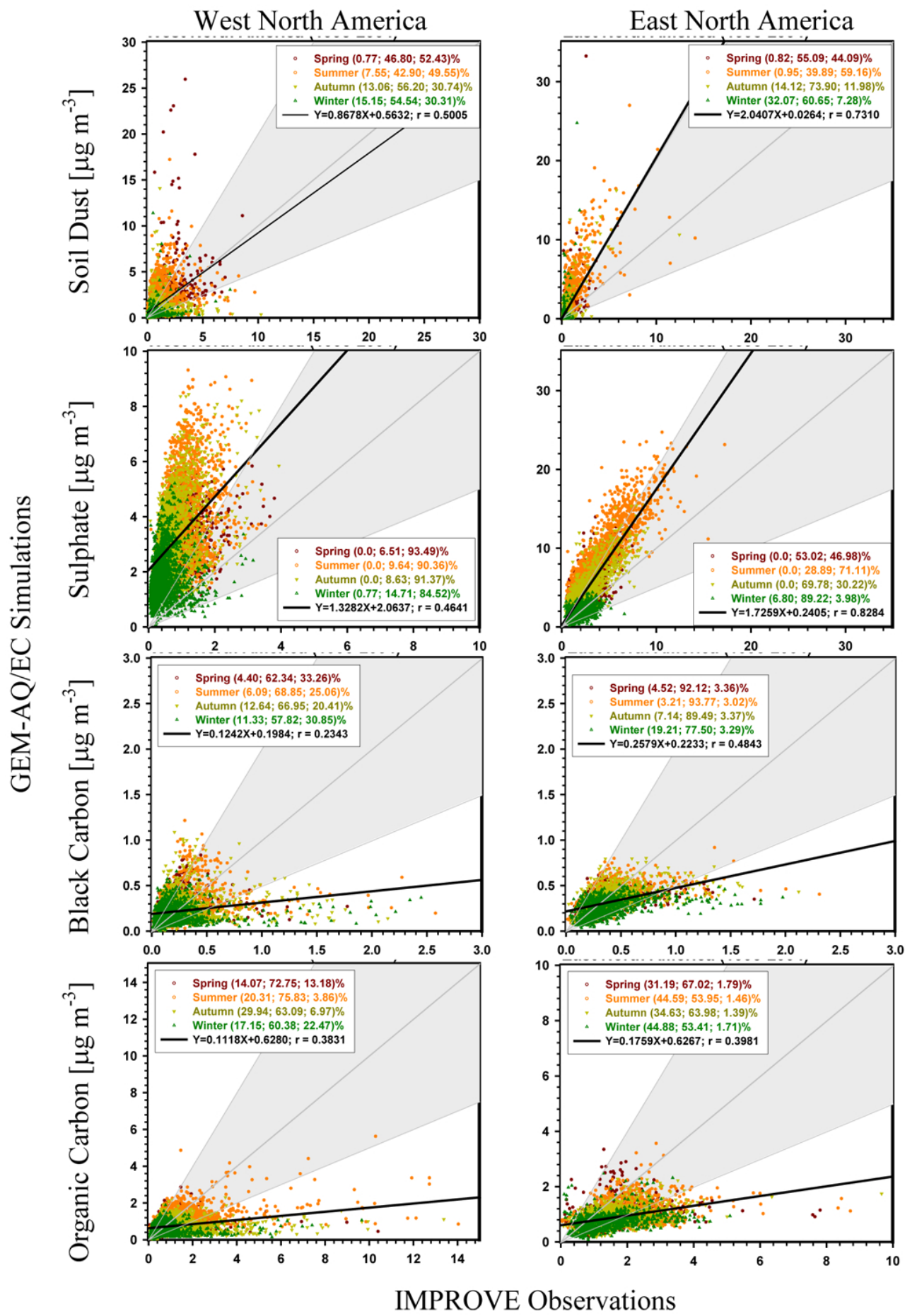

Fig. 9. Comparisons of model predicted concentrations of four major aerosol species in North America with IMPROVE network observations. West and East North Americas are compared separately. Legend explanations are given the same as in Fig. 7.

in the current paper, does not take into account the variability in amounts of fuel consumed from month to month, except for Canada. Therefore, the method underpredicts emissions, including those of $\mathrm{BC}$ and $\mathrm{OC}$, from fires during drier than normal years. A new version of the boreal fire emis- sions is currently under development. It will include the influence of daily variation of weather conditions on fuel consumed amounts across the whole boreal vegetation. Regarding injection heights, aerosols from fire emissions are injected at different altitudes, depending on type of vegetation, 
(a) Spring

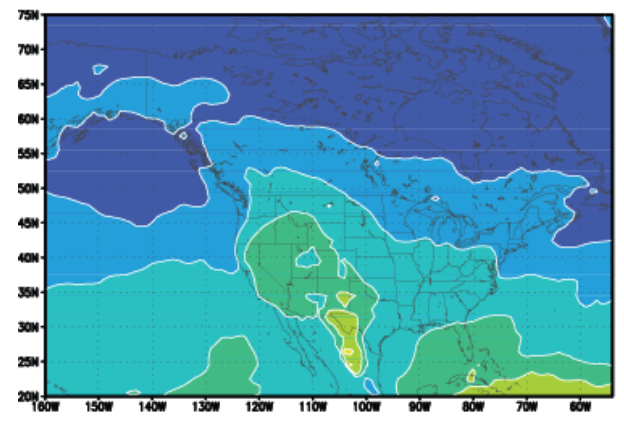

(c) Fall

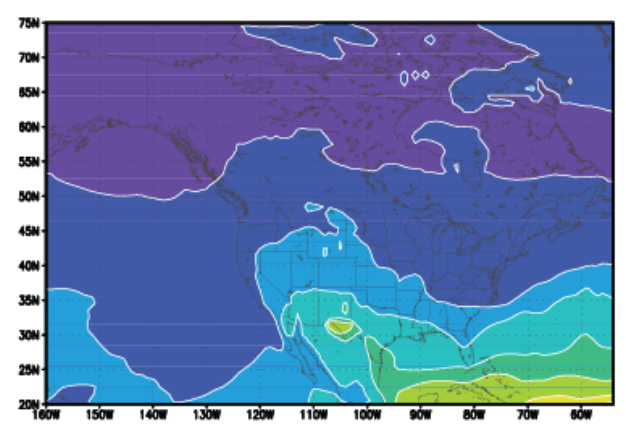

(b) Summer

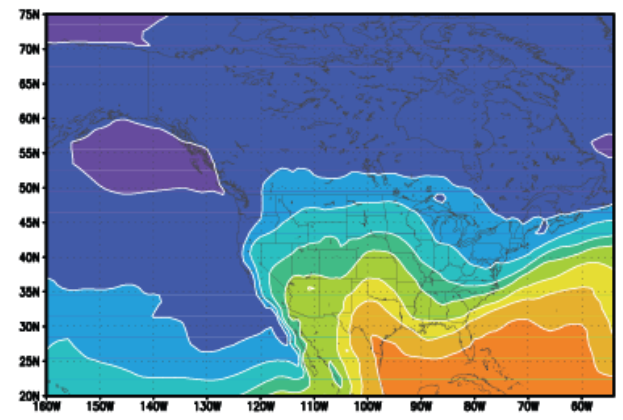

(d) Winter

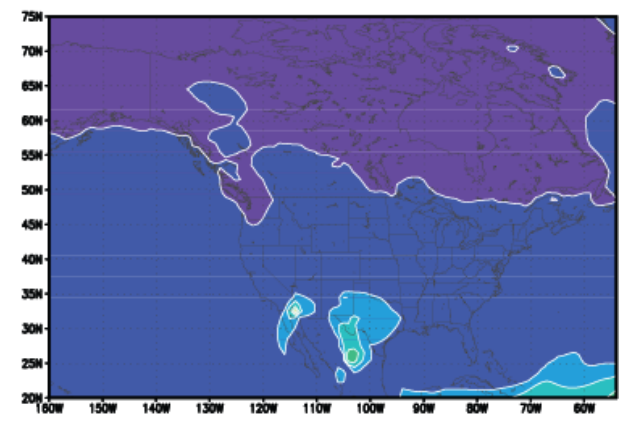

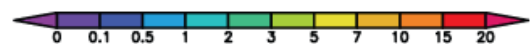

Fig. 10. Seasonal dust aerosol distributions $\left(\mu \mathrm{g} \mathrm{m}^{-3}\right)$ in North America and influence of trans-Atlantic transport of dust from Africa.

weather conditions, and thus the nature of the fire. The technique used in the present study follows the vertical distribution of smoke in the model layers, already used in the AeroCom study (Dentener et al., 2006). The injection heights are set to constant values for various geographical areas; for example, $4-5 \mathrm{~km}$ in boreal North America and $2-3 \mathrm{~km}$ for other regions. Therefore, the bias of OC prediction could be caused by "misplaced" injection heights for specific years or months. However, considering the seasonality of injection heights would mean taking into account the weather conditions in the calculation of the plume heights over $10 \mathrm{yr}$, which was beyond the scope of our modelling study. The next version of the boreal fire emission datasets is currently under development and will integrate the seasonal variability of the emissions heights following the method detailed in Lavoué et al. (2007).

Positive biases are found for NA dust and sulphate aerosols. The dust aerosols are over-predicted by a factor of 2 for the east NA with a slightly negative bias for the west NA. Given the fact that most of the wind-blown sources is in the west, the over-estimate is a little unusual. If the anthropogenic dust (i.e. fugitive dust) were added into the model, the over-estimate in the east would be even larger. However, a detailed analysis of the seasonal variation of the comparisons reveals that most of the over-estimate of dust aerosols in east
NA occurs in spring and summer, which coincides with the peak trans-Atlantic transport of African dust to North America (Fig. 10a and b). For fall and winter (Fig. 10c and d) when the continental America is less impacted by the African dust, the model performance is much better, indicating that the model has over-estimated the trans-Atlantic transport of dust. Three factors are attributable for the over-estimate, i.e. dust emission, transport and removal processes. More observational data is needed to identify the dominant factors and to improve the model performance.

For sulphate, the over-prediction is about 1.6 and 1.9 for the west and east NA, respectively. Given the fact that the anthropogenic emission of sulphur used for the 10-yr simulations in this study was from GEIA for the mid-1980's, the overestimate may be primarily due to larger emissions in North America for GEIA than for the simulation and observational periods of 1995 to 2004. Stern (2005) estimated about $30 \%$ decrease of sulphur emissions in North America from 1985 to 2000 with further drop to 2007 (Gong et al., 2010).

Severe negative biases are found for NA carbonaceous aerosols. The model predictions only yielded about $20 \%$ of observed concentrations with much lower correlation coefficients compared to the soil dust and sulphate aerosols. Since nitrate aerosol was not considered in this study, the total 


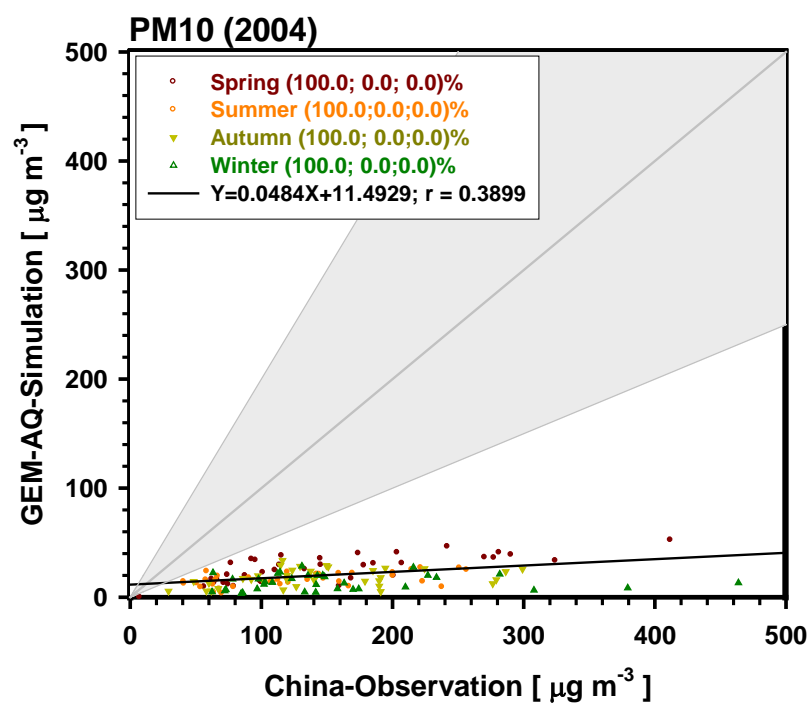

Fig. 11. Comparisons of model predicted PM concentrations in China with CAWNET network observations in 2004. Legend explanations are given the same as in Fig. 7.

under-estimation of PM in NA is a consequence of the underprediction of carbonaceous aerosols and the ignorance of nitrate aerosols.

The uncertainty in emissions is more obvious for the simulation in Asia. Though a relatively good correlation between modeled and observed $\mathrm{PM}_{10}$ was achieved, the model severely under-estimated the concentration for all months and stations (Fig. 11). The sulphur emissions in Asia have increased more than $20 \%$ from 1985 to 2000 (Stern, 2005) while Zhang et al. (2009) have shown an increasing trend during 2001-2006 for China: 36\% increase for $\mathrm{SO}_{2}, 55 \%$ for $\mathrm{NO}_{\mathrm{x}}, 18 \%$ for $\mathrm{CO}, 29 \%$ for $\mathrm{VOC}, 13 \%$ for $\mathrm{PM}_{10}$, and $14 \%$ for $\mathrm{PM}_{2.5}, \mathrm{BC}$, and $\mathrm{OC}$. This changing trend in emissions has contributed to the discrepancy between model simulated and observed aerosol concentrations in Asia. More accurate emissions in terms of spatial and temporal resolutions are needed to better simulate aerosol concentrations in Asia.

\subsection{Seasonal variations}

Due to the seasonal variations in emissions and meteorology, aerosols also exhibit certain degree of seasonal variations. Figure 12 shows the simulated and observed seasonal variations of $\mathrm{PM}_{2.5}$ and $\mathrm{PM}_{10}$ averaged over the observational points in North America and Europe. For both North America and Europe, the model predicts a summer high of PM concentrations that are agreed well with observations in NA but not in Europe where no obvious seasonal variations are observed for the averaged concentrations. For NA, the agreement for $\mathrm{PM}_{2.5}$ is rather good in terms of both seasonal variations and magnitudes while for $\mathrm{PM}_{10}$ the agreement is very good for the seasonal variations but not for the magnitudes. It is noticed that the European observations have a very large standard deviation in the first and last three months of the year when the model and observation are deviated. Seasonal variation in the anthropogenic emission regions is difficult to accurately predict as it requires the accurate seasonal pattern of emissions in addition to the realistic simulation of meteorology which controls the deposition and transports.

Figure 13 is a comparison of simulated soil dust concentrations with observed data from selected monitoring stations. The model reached reasonable agreement with the observed concentrations and seasonal variations at these locations. These seasonal variations reflect the sources and transport changes during the year, regulated by the global general circulation variability. The three remote stations over the Pacific, i.e. Cheju, Midway over Oahu, have a spring peak, which is contributed from the spring soil dust emission and transport from the Asian continent. On the other hands, the stations in the Atlantic and its coast, i.e. Rsmas, Bermuda and Barbados, present a summer peak which is contributed from the trans-Atlantic transport of dust aerosols from Africa (Fig. 10b). This seasonal variation is consistent with the observations of structure and variability of aerosols over Africa, the Atlantic, and the Americas by CALIPSO (Cloud -Aerosol Lidar Infrared Pathfinder Satellite Observations) (Adams, 2011). It is interesting to note that the dust spring peaks in Asia and Pacific follow the peak emissions (Fig. 4) and transport in spring by westerly. However, even though the peak emission of dust in Africa appears in spring (Fig. 4), the dust concentrations over the Atlantic and its coast peak in summer. This is probably caused by the seasonal variations of the trans-Atlantic transports by the easterly waves which maximize in summer (Jones et al., 2003) to bring more dust into the Atlantic ocean and the east part of North America.

\section{Relative Contribution of natural vs. anthropogenic origins}

Global aerosols consist of a much larger fraction of natural components including soil dust, sea-salt and bio-mass burning aerosols than those from anthropogenic origins. Natural sources of aerosols are probably 4 to 5 times larger than anthropogenic ones on a global scale. A recent review indicates that the global annual emissions could reach as high as $16300 \mathrm{Tg}$ for sea-salt (Textor et al., 2006) and $1600 \mathrm{Tg}$ for soil dust (Kaufman et al., 2005b). An accurate simulation of these natural components is critical to obtain correct global aerosol distributions. The simulations in this study tag the natural aerosol components of soil dust, sea-salt and BC/OC and thus enable the assessment of natural contributions to the global aerosol background concentrations from which the anthropogenic contributions are superimposed. The global distribution of sea-salt aerosol has been studied extensively 
PM2.5
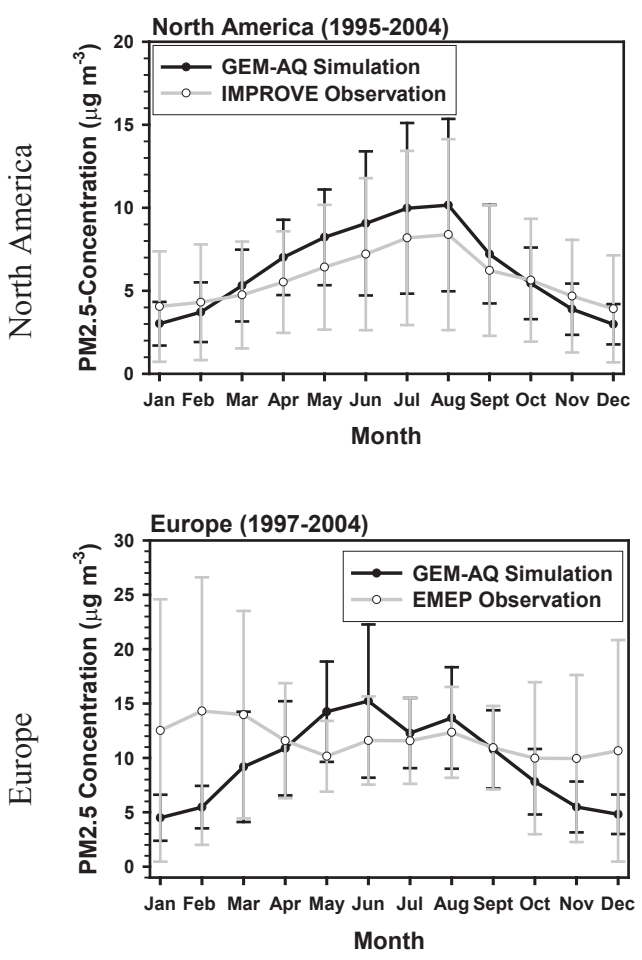

PM10
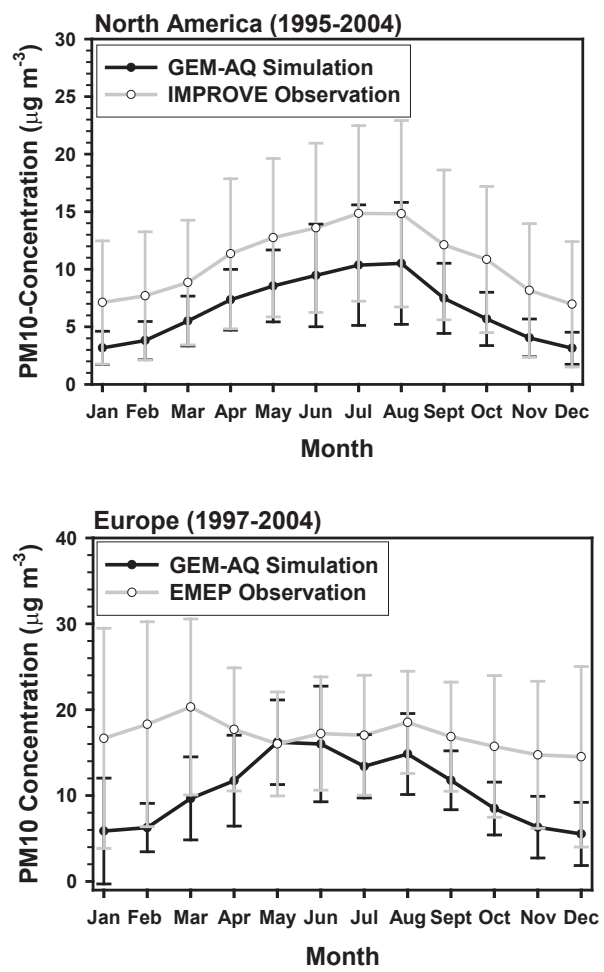

Fig. 12. Comparisons of simulated monthly $\mathrm{PM}_{2.5}$ and $\mathrm{PM}_{10}$ concentrations in North America and Europe with observations.

and reasonable results are achieved (Gong and Barrie, 2003; Gong et al., 1997a). The model evaluations in Sect. 3, especially the spatial and temporal correlations, indicated that the model is able to capture the general spatial and temporal distributions of various aerosol properties including AOD and mass concentrations.

The relative contribution of natural aerosols to the global background concentrations are obtained from the $10 \mathrm{yr}$ simulations. Over the oceans in the roaring southern 40 and midlatitude Northern Hemisphere, sea-salt aerosol is the dominant aerosol species. This can be seen from both satellite observations (Fig. 14a) and modeling results (Fig. 14b). In the regions where anthropogenic aerosols dominate as indicated by the red pixels in Fig. 14 such as in Europe, East NA and East Asia, the model predicts less than $20 \%$ natural contributions. Over the major continental natural source regions such as in northern Africa, south-west NA and central Asia as indicated by the green pixels in Fig. 14a, the predicted natural contributions can range from $50 \%$ to about $100 \%$.

Natural aerosols have not only inter-annual variations but also seasonal changes. For the $10 \mathrm{yr}$ simulations, the percentage contribution to the total PM can reach as high as $10 \%$ in some regions due to the inter-annual variability of meteorology, especially in the tropic and equatorial regions (Fig. 14b). The seasonal variation of natural aerosols depends on the species and locations. Asian dust aerosols peak in the spring and are transported over the Pacific Ocean. This is illustrated in the observed and modeled dust concentrations at Cheju, Oahu and Midway (Fig. 13). Strong seasonal variations are found for the global sea-salt fluxes in both Northern and Southern Hemispheres. A winter high with respect to each hemisphere is predicted. Sea-salt concentrations are highest in the roaring forties of the Southern Hemisphere and over the northern oceans from October to March, which is consistent with the emission patterns of sea-salt aerosol (Fig. 3). Bio-mass burning aerosols from natural sources i.e. boreal forests (Fig. 5), peak in the summer and contribute to the background aerosols in the northern high latitudes and in the Arctic.

It should be noted that the current assessment of the relative contributions of natural aerosols to the global total distributions is subject to large uncertainties due to the large uncertainties in the emission estimates. For example, the estimate of annual dust emission in this study was around $4 \mathrm{Tg} \mathrm{yr}^{-1}$ or $0.2 \%$ of global dust budget, compared to the $3 \%$ from $\mathrm{Gi}-$ noux et al. (2001). Furthermore, the current study found that Russia and Canada were the main biomass burning source in the North Hemisphere while other study has found that the US and Central America sources might be more important (Wiedinmyer et al., 2006). 


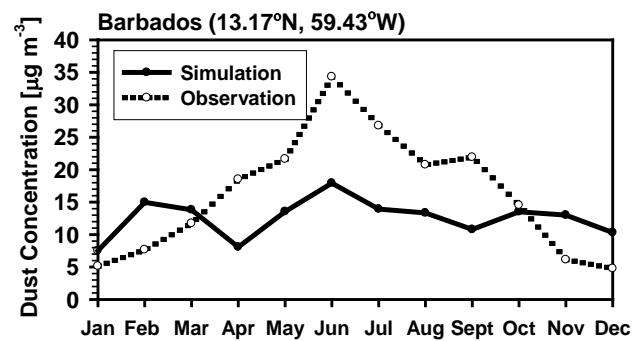

Month

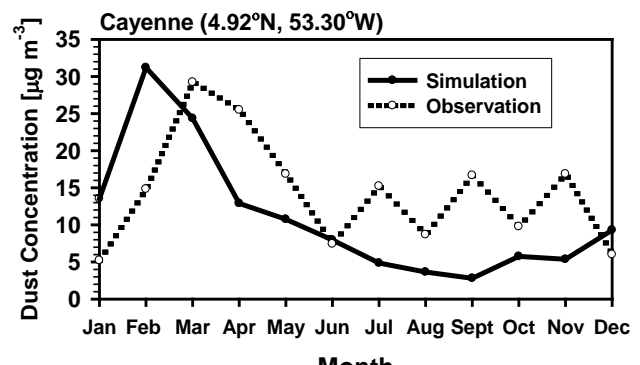

Month

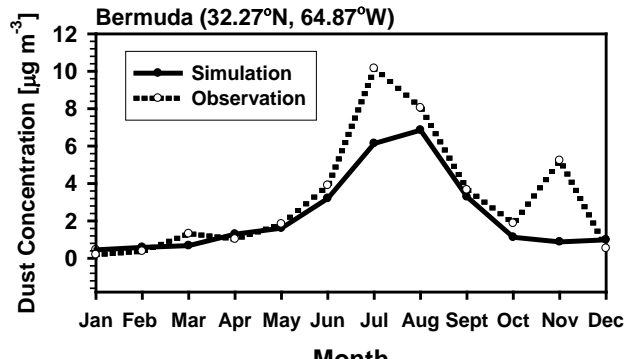

Month

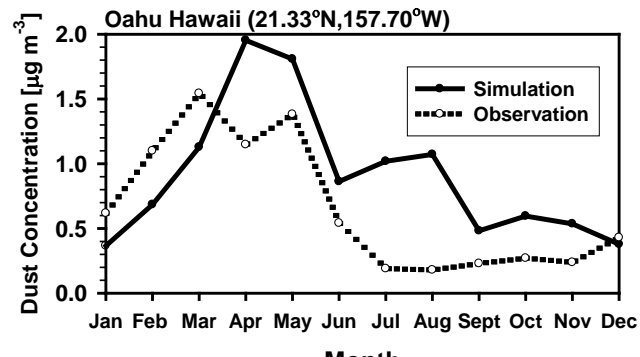

Month

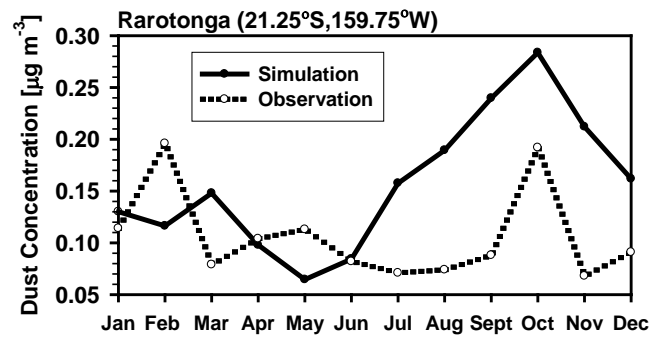

Month

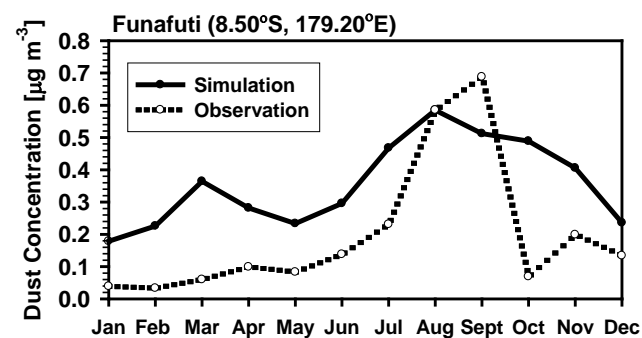

Month
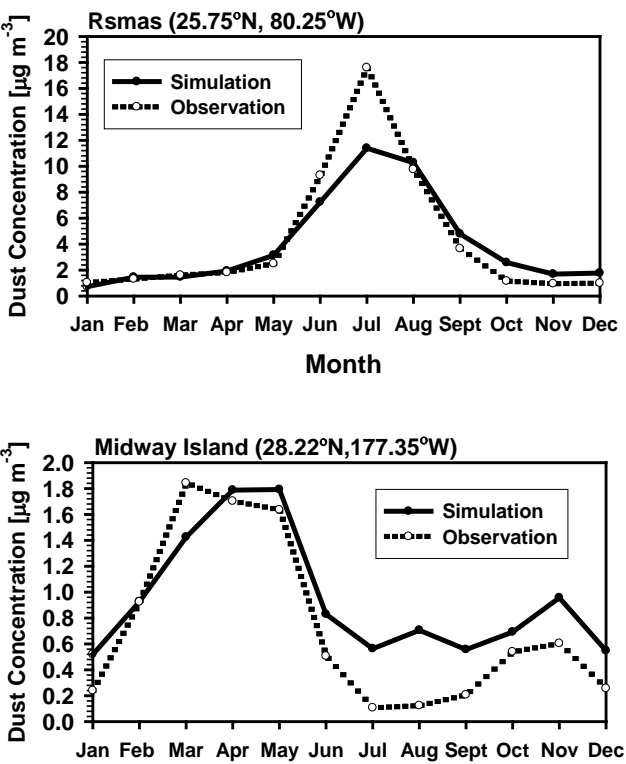

Month

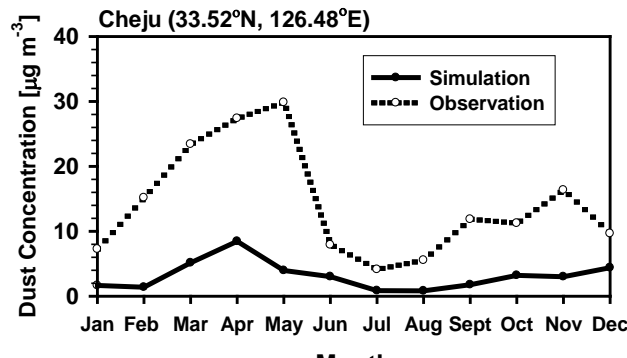

Month

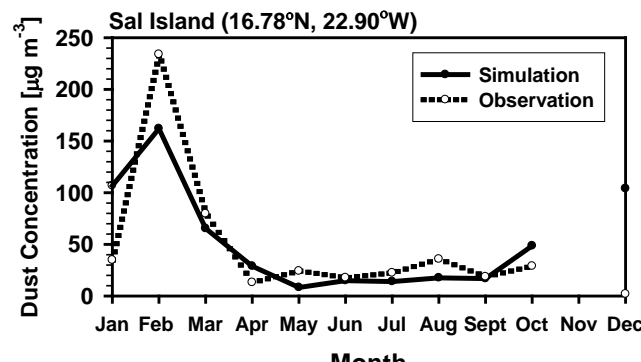

Month

Fig. 13. Comparisons of monthly averaged surface soil dust concentrations for 1995-2004 with observations at Miami University research stations. 

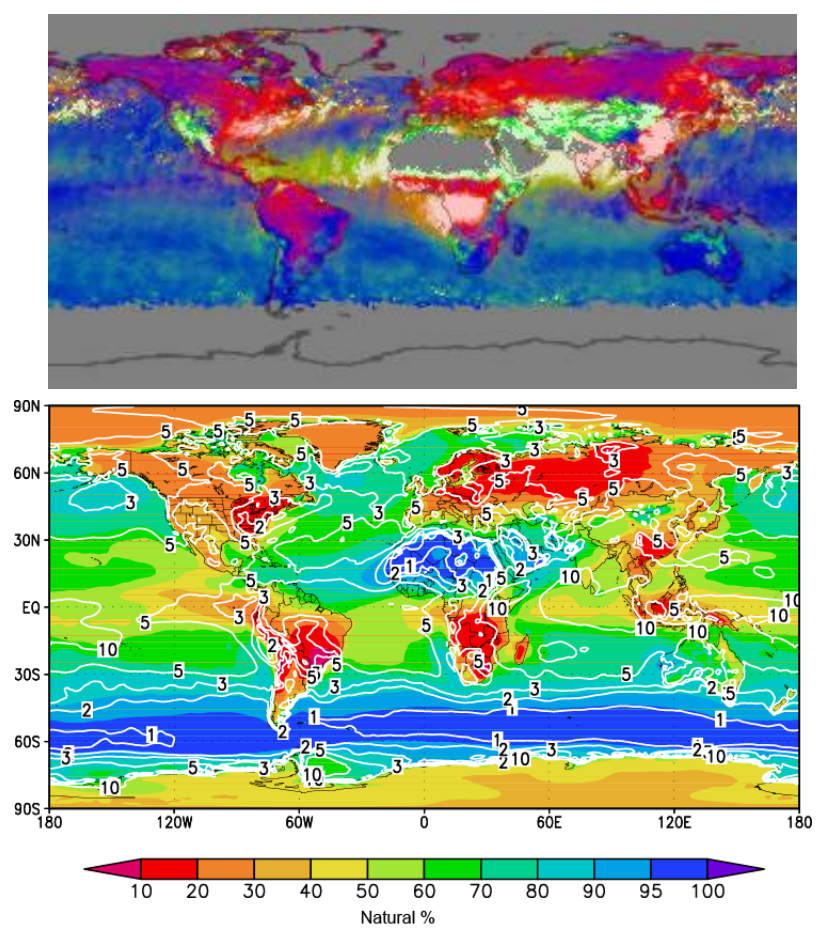

Fig. 14. (a) This false color image is a map of natural aerosols (green pixels), human pollution (red pixels), or a mixture of both (light brown pixels). Gray areas indicate a lack of usable data. This map covers pollution measured between January 2001 and July 2002. (b) Global distribution of the averaged percentages of natural aerosol contributions to total aerosols (shading) with the standard deviations (contour lines) of the percentages from the $10 \mathrm{yr}$ modeling.

\section{Conclusions}

A global on-line air quality modeling system with size segregated aerosol scheme was developed and utilized to simulate the global aerosol emissions and climatology for $10 \mathrm{yr}$. The inter-annual variability and seasonal cycle of emissions of sea-salt, soil dust, black carbon, and organic matter for biomass burning was investigated from 1995-2004. Canadian wildfire emissions for 2000-2004 integrated in the emission inventories were calculated with a state-of-the-art modeling technique, including a semi-empirical fire behaviour model.

Reasonable agreements, especially the spatial and temporal correlations, are achieved with observations, indicating that the model is able to capture the general spatial and temporal distributions of various aerosol properties including AOD and mass concentrations. The large discrepancy between model simulated and observed concentrations is mainly due to the emissions used in this application. The model performance is generally better in North America than in Europe and Asia with the best in the east North America.

In the regions where anthropogenic aerosols dominate such as in Europe, East NA and East Asia, the model pre- dicts less than $20 \%$ natural contributions. Over the major continental natural source regions such as in northern Africa, south-west NA and central Asia the predicted natural contributions can range from $50 \%$ to about $100 \%$. Natural aerosols present larger seasonal variations than the anthropogenic aerosols and have strong inter-annual variability associated the fluctuation in meteorology.

The variability in global aerosols is complicated by the tempo-spatial changes of emissions as well as by the interannual variations of meteorology. The influence of meteorological factors is difficult to distinguish from observations. Although the accuracy in the emission sources may have played an important role in the aerosol simulation, the 10-yr modeling of global aerosols with respect to the mean climate of hemispheric transport provides a way to isolate the meteorological influence on the aerosol variability through an analysis of the 10-yr aerosol modeling, which is presented in the companion paper published (Zhao et al., 2012) focusing on the inter-annual variability of HTAP and the meteorological contributions.

\section{Appendix A}

Methodology in computing the Carbonaceous Aerosol Emissions from Boreal and Temperate Vegetation Fires.

\section{A1 North America}

For Canada, hourly emissions were calculated with a fire growth parameterization, a fire behavior prediction model, and modelled surface weather conditions for the years 2000 2004 (Lavoué et al., 2007; Lavoué and Stocks, 2011). From 1995 through 1999, the large fire database $(200+$ hectares $)$ of (Stocks et al., 2003) was used. This dataset provides the start date, geographical location, and final size of every fire in the records. However, the extinction date is not systematically included by provincial protection agencies. To address this issue, a statistical analysis of fifteen large fires, for which the area growth was recorded by the agencies, was performed to determine a linear relationship between the final size and the length of the burning time period (Table 2). By applying a daily fire growth rate depending on the final size, it was possible to estimate an extinction date for all the fires in the large fire database.

With respect to the United States, the National Interagency Fire Center prepared situation reports for ten geographic areas of contiguous US (http://www.nifc.gov/nicc/index.htm, accessed 16 March 2011) on a daily basis during the fire season and every week otherwise. Monthly areas burned in all geographic areas were derived from this dataset. Fire regions inside each area were redistributed in space according to the occurrence of ATSR fire pixels during 1995-2001 and MODIS hotspots for the following years. Finally, the 
US Bureau of Land Management makes available the Alaska fire scar location database on their web site (Table 1). The database includes annual perimeters of fires greater than 50 hectares in the ArcINFO format easily integrated into our GIS application.

For Mexico, the National Forestry Commission (CONAFOR) makes areas burned in most of the 32 States available on their web site. In addition, during the task of compiling fire data, monthly variability was given only for 1995 and 1996. Consequently, ATSR fire counts were used to set respective seasonal cycles for all other years.

\section{A2 Europe}

Regarding Europe, reliable fire statistics for most of the countries permit constraining areas burned on an annual or even a monthly basis. Inventories of areas burned were compiled from multiple sources including technical reports, statistics available on web sites of respective Ministries of the Environment, and information compiled and disseminated by the United Nation Food and Agriculture Organization. Table 1 summarizes all the information scrutinized by countries in Eastern, Northern, Southern, and Western Europe. In the eastern, northern, and western regions of Europe, fire activity is relatively limited and statistics are usually restricted to annual data and are provided at the scale of a country or by jurisdiction (e.g. the Laender for Germany). However, statistics are more complete on a monthly basis and at the administrative unit level in countries of Southern Europe where large vegetation fires may occur. For instance, Spain, Portugal, Italy, and France have maintained comprehensive records on fire activity in their Mediterranean ecosystems.

\section{A3 North Africa and Middle East}

Ground-based statistics related to fires occurring in the rest of the Mediterranean basin is much more limited. Only annual areas burned are available, sometimes as best guess, for most of the countries in North Africa and Middle East, with the exception of Turkey, for which information on fire locations and seasonality by ecosystems were published (Table 1).

\section{A4 Boreal Eurasia}

For Russia, annual areas burned for 1996 to 2002 were assessed from AVHRR (Advanced Very High Resolution Radiometer) imagery by Sukhinin et al. (2004a, b). Datasets are available as GIS shape files at the Global Land Cover Facility web site (Table 1). In addition, similar remote sensing 3 analysis exists for subsequent years 2003 and 2004 on the Global Fire Monitoring Center web site (Table 1). Next, ATSR fire counts were employed as proxies to derive the monthly distribution in every grid cell. Finally, a forest fuel map was built from the Russian vegetation mapping completed by the International Institute for Applied System Analysis (http:
//www.iiasa.ac.at/Research/FOR/russia_cd/for.htm, accessed 21 December 2010).

With respect to Mongolia, the analysis of remote sensing data is currently the best option for assessing the geographical extent of wildland fires in Mongolia since it is one of the scarcest inhabited countries in the world (Table 1). Burn scars from AVHRR imagery permitted building a gridded area burned inventory for the whole $10 \mathrm{yr}$-study. Furthermore, a $1^{\circ} \times 1^{\circ}$ Mongolian vegetation fuel map was derived from the $1 \mathrm{~km} \times 1 \mathrm{~km}$ vegetation map of the US Geological Survey (https://research.cip.cgiar.org/gis/index.php, accessed 16 March 2011).

Acknowledgements. The authors wish to thank CFCAS (The Canadian Foundation for Climate and Atmospheric Sciences) for its partial finical support for this research through the NW AQ MAQNet Grant. This research was also partially supported by the National Key Research Project (2011CB403404) of the Ministry of Science and Technology of China.

Edited by: E. Vignati

\section{References}

Adams, A. M.: Climatology and Variability of Aerosol over Africa, the Atlantic, and the Americas, Open Access Theses., 273 pp., 2011.

Adhikary, B., Carmichael, G. R., Kulkarni, S., Wei, C., Tang, Y., D'Allura, A., Mena-Carrasco, M., Streets, D. G., Zhang, Q., Pierce, R. B., Al-Saadi, J. A., Emmons, L. K., Pfister, G. G., Avery, M. A., Barrick, J. D., Blake, D. R., Brune, W. H., Cohen, R. C., Dibb, J. E., Fried, A., Heikes, B. G., Huey, L. G., O'Sullivan, D. W., Sachse, G. W., Shetter, R. E., Singh, H. B., Campos, T. L., Cantrell, C. A., Flocke, F. M., Dunlea, E. J., Jimenez, J. L., Weinheimer, A. J., Crounse, J. D., Wennberg, P. O., Schauer, J. J., Stone, E. A., Jaffe, D. A., and Reidmiller, D. R.: A regional scale modeling analysis of aerosol and trace gas distributions over the eastern Pacific during the INTEX-B field campaign, Atmos. Chem. Phys., 10, 2091-2115, doi:10.5194/acp-10-20912010, 2010.

Akimoto, H.: Global Air Quality and Pollution, Science, 302, 17161719, 2003.

Ayash, T., Gong, S. L., and Jia, C.: Direct and indirect shortwave radiative effects of sea salt aerosols, J. Climate, 21, 3207-3220, 2008.

Baron, R. E., Montgomery, W. D., and Tuladhar, S. D.: An Analysis of Black Carbon Mitigation as a Response to Climate Change, Copenhagen Consensus Center, 31, 2009.

Berntsen, T., Isaksen, I. S. A., Wang, W. C., and Liang, X. Z.: Impacts of increased antrhopogenic emissions in Asia on tropospheric ozone and climate: A global 3-D model study., Tellus, 48B, 13-32, 1996.

Chin, M., Ginoux, P., Kinne, S., Torres, O., Holben, B. N., Duncan, B. N., Martin, R. V., Logan, J. A., Higurashi, A., and Nakahima, T.: Tropospheric aerosol optical thickness from the GOCART model and comparisons with satellite and sunphotometer measurements, J. Atmos. Sci., 59, 461-483, 2002. 
Cooke, W. F., Liousse, C., and Cachier, H.: Construction of a $1^{\circ}$ $\mathrm{x} 1^{\circ}$ fossil fuel emission data set for carbonaceous aerosol and implementation and radiative impact in the ECHAM4 model, J. Geophys. Res., 104, 22137-22162, 1999.

Côté, J., Desmarais, J.-G., Gravel, S., Méthot, A., Patoine, A., Roch, M., and Staniforth, A.: The operational CMC/MRB Global Environmental Multiscale (GEM) model. Part I: Design considerations and formulation, Mon. Weather Rev., 126, 1373-1395, 1998.

Dentener, F., Kinne, S., Bond, T., Boucher, O., Cofala, J., Generoso, S., Ginoux, P., Gong, S., Hoelzemann, J. J., Ito, A., Marelli, L., Penner, J. E., Putaud, J.-P., Textor, C., Schulz, M., van der Werf, G. R., and Wilson, J.: Emissions of primary aerosol and precursor gases in the years 2000 and 1750 prescribed data-sets for AeroCom, Atmos. Chem. Phys., 6, 4321-4344, doi:10.5194/acp-64321-2006, 2006.

EPA, U. S.: National Ambient Air Quality Standards for Particulate Matter: Final Rule, Federal Register, 62, 38651-38760, 1997.

Fécan, F., Marticorena, B., and Bergametti, G.: Parametrization of the increase of the aeolian erosion threshold wind friction velocity due to soil moisture for arid and semi-arid areas, Ann. Geophys., 17, 149-157, doi:10.1007/s00585-999-0149-7, 1999.

Fiore, A. M., Dentener, F. J., Wild, O., Cuvelier, C., Schultz, M. G., Hess, P., Textor, C., Schulz, M., Doherty, R. M., Horowitz, L. W., MacKenzie, I. A., Sanderson, M. G., Shindell, D. T., Stevenson, D. S., Szopa, S., Dingenen, R. V., Zeng, G., Atherton, C., Bergmann, D., Bey, I., Carmichael, G., Collins, W. J., Duncan, B. N., Faluvegi, G., Folberth, G., Gauss, M., Gong, S., Hauglustaine, D., Holloway, T., Isaksen, I. S. A., Jacob, D. J., Jonson, J. E., Kaminski, J. W., Keating, T. J., Lupu, A., Marmer, E., Montanar, V., Park, R. J., Pitari, G., Pringle, K. J., Pyle, J. A., Schroeder, S., Vivanco, M. G., Wind, P., Wojcik, G., Wu, S., and Zuber, A.: Multimodel estimates of intercontinental source-receptor relationships for ozone pollution, J. Geophys. Res., 114, D04301, doi:10.1029/2008JD010816, 2009.

Flanner, M. G., Zender, C. S., Randerson, J. T., and Rasch, P. J.: Present-day climate forcing and response from black carbon in snow, J. Geophys. Res., 112, D11202, doi:10.1029/2006JD008003, 2007.

Generoso, S., Bréon, F.-M., Balkanski, Y., Boucher, O., and Schulz, M.: Improving the seasonal cycle and interannual variations of biomass burning aerosol sources, Atmos. Chem. Phys., 3, 12111222, doi:10.5194/acp-3-1211-2003, 2003.

Giglio, L., van der Werf, G. R., Randerson, J. T., Collatz, G. J., and Kasibhatla, P.: Global estimation of burned area using MODIS active fire observations, Atmos. Chem. Phys., 6, 957974, doi:10.5194/acp-6-957-2006, 2006.

Ginoux, P., Chin, M., Tegen, I., Prospero, J. M., Holben, B., Dubovik, O., and Lin, S.-J.: Sources and distributions of dust aerosols simulated with the GOCART mode, J. Geophys. Res., 106, 20255-20274, 2001.

Ginoux, P., Prospero, J. M., Torres, O., and Chin, M.: Longterm simulation of global dust distribution with the GOCART model: correlation with North Atlantic Oscillation, Environ. Model. Softw., 19, 113-128, doi:10.1016/S13648152(03)00114-2, 2004.

Gong, S. L.: A parameterization of sea-salt aerosol source function for sub- and super-micron particles, Global Biogeochem. Cy., 17, 1097, doi:10.1029/2003GB002079, 2003.
Gong, S. L. and Barrie, L. A.: Simulating the Impact of Sea-salt on Global nss-Sulphate Aerosols, J. Geophys. Res., 108, 4516, doi:10.1029/2002JD003181, 2003.

Gong, S. L., Barrie, L. A., and Blanchet, J.-P.: Modeling sea-salt aerosols in the atmosphere. Part 1: Model development, J. Geophys. Res., 102, 3805-3818, 1997a.

Gong, S. L., Barrie, L. A., Prospero, J. M., Savoie, D. L., Ayers, G. P., Blanchet, J.-P., and Spacek, L.: Modeling sea-salt aerosols in the atmosphere - 2. Atmospheric concentrations and fluxes, J. Geophys. Res., 102, 3819-3830, doi:10.1029/96JD03401, $1997 b$.

Gong, S. L., Barrie, L. A., Blanchet, J.-P., and Spacek, L.: Modeling size-segregated sea salt aerosols in the atmosphere: an application using Canadian climate models, in: Air pollution modeling and its application XII, edited by: Gryning, S.-E. and Chaumerliac, M., Plenum, New York, 337-345, 1998.

Gong, S. L., Barrie, L. A., and Lazare, M.: Canadian Aerosol Module (CAM): A size-segregated simulation of atmospheric aerosol processes for climate and air quality models -2 . Global sea-salt aerosol and its budgets, J. Geophys. Res., 107, 4779, doi:10.1029/2001JD002004, 2002.

Gong, S. L., Barrie, L. A., Blanchet, J.-P., Salzen, K. v., Lohmann, U., Lesins, G., Spacek, L., Zhang, L. M., Girard, E., Lin, H., Leaitch, R., Leighton, H., Chylek, P., and Huang, P.: Canadian Aerosol Module: A size-segregated simulation of atmospheric aerosol processes for climate and air quality models 1. Module development, J. Geophys. Res., 108, 4007, doi:10.1029/2001JD002002, 2003a.

Gong, S. L., Zhang, X. Y., Zhao, T. L., McKendry, I. G., Jaffe, D. A., and Lu, N. M.: Characterization Of Soil Dust Distributions In China And Its Transport During ACE-ASIA 2. Model Simulation and Validation, J. Geophys. Res., 108, 4262, doi:10.1029/2002JD002633, 2003b.

Gong, S. L., Zhang, X. Y., Zhao, T. L., Zhang, X. B., Barrie, L. A., McKendry, I. G., and Zhao, C. S.: A simulated climatology of Asian dust aerosol and its trans-Pacific transport. Part II: Interannual variability and climate connections, J. Climate, 19, 104122, 2006.

Gong, S. L., Zhao, T. L., Sharma, S., Toom-Sauntry, D., Lavoué, D., Zhang, X. B., Leaitch, W. R., and Barrie, L. A.: Identification of trends and interannual variability of sulfate and black carbon in the Canadian High Arctic: 1981-2007, J. Geophys. Res., 115, D07305, doi:10.1029/2009JD012943, 2010.

Governing Council of the United Nations Environment Programme: Integrated assessment of black carbon and tropospheric ozone Summary for decision makers Nairobi, 37, 2011.

Grini, A., Myhre, G., Sundet, J., and Isaksen, I. S. A.: Modeling the annual cycle of sea salt in the global 3D model Oslo CTM2: concentrations, fluxes, and radiative input, J. Climate, 15, 17171730, 2002.

HTAP: HEMISPHERIC TRANSPORT OF AIR POLLUTION 2010, UNITED NATIONS, New York and Geneva, 2010.

Huneeus, N., Schulz, M., Balkanski, Y., Griesfeller, J., Prospero, J., Kinne, S., Bauer, S., Boucher, O., Chin, M., Dentener, F., Diehl, T., Easter, R., Fillmore, D., Ghan, S., Ginoux, P., Grini, A., Horowitz, L., Koch, D., Krol, M. C., Landing, W., Liu, X., Mahowald, N., Miller, R., Morcrette, J.-J., Myhre, G., Penner, J., Perlwitz, J., Stier, P., Takemura, T., and Zender, C. S.: Global dust model intercomparison in AeroCom phase I, Atmos. Chem. 
Phys., 11, 7781-7816, doi:10.5194/acp-11-7781-2011, 2011.

IPCC: Climate Change 2007: The Physical Science Basis: Contribution of Working Group I to the Fourth Assessment Report of the Intergovernmental Panel on Climate Change, edited by: Solomon, S., Qin, D., Manning, M., Chen, Z., Marquis, M., Averyt, K. B., Tignor, M., and Miller, H. L., Cambridge, United Kingdom and New York, NY, USA, 996 pp., 2007.

Jacob, D. J. and Winner, D. A.: Effect of climate change on air quality, Atmos. Environ., 43, 51-63, 2009.

Jacobson, M. Z.: Short-term effects of controlling fossil-fuel soot, biofuel soot and gases, and methane on climate, Arctic ice, and air pollution health, J. Geophys. Res., 115, D14209, doi:10.1029/2009JD013795, 2010.

Jones, C., Mahowald, N., and Luo, C.: The role of easterly waves on African desert dust transport, J. Climate, 16, 3617-3628, doi:10.1175/1520-0442(2003)016<3617:TROEWO > 2.0.CO;2, 2003.

Kaminski, J. W., Neary, L., Struzewska, J., McConnell, J. C., Lupu, A., Jarosz, J., Toyota, K., Gong, S. L., Côté, J., Liu, X., Chance, K., and Richter, A.: GEM-AQ, an on-line global multiscale chemical weather modelling system: model description and evaluation of gas phase chemistry processes, Atmos. Chem. Phys., 8, 3255-3281, doi:10.5194/acp-8-3255-2008, 2008.

Kandlikar, M., Reynolds, C. C. O., and Grieshop, A. P.: A Perspective Paper on Black Carbon Mitigation as a Response to Climate Change, Copenhagen Consensus Center, 20, 2009.

Kaufman, Y. J., Tanrë, D., and Boucher, O.: A satellite view of aerosols in the climate system, Nature, 419, 215-223, doi:10.1038/nature01091, 2002.

Kaufman, Y. J., Koren, I., Remer, L. A., Tanré, D., Ginoux, P., and Fan, S.: Dust transport and deposition observed from the Terra-Moderate Resolution Imaging Spectroradiometer (MODIS) spacecraft over the Atlantic Ocean, J. Geophys. Res., 110, D10S12, doi:10.1029/2003JD004436, 2005a.

Kaufman, Y. J., Koren, I., Remer, L. A., Tanré, D., Ginoux, P., and Fan, S.: Dust transport and deposition observed from the Terra-Moderate Resolution Imaging Spectroradiometer (MODIS) spacecraft over the Atlantic Ocean, J. Geophys. Res., 110, D10S12, doi:10.1029/2003JD004436, 2005 b.

Kim, S.-W., Yoon, S.-C., Kim, J., Kang, J.-Y., and Sugimoto, N.: Asian dust event observed in Seoul, Korea, during 29-31 May 2008: Analysis of transport and vertical distribution of dust particles from lidar and surface measurements, Sci. Total Environ., 408, 1707-1718, doi:10.1016/j.scitotenv.2009.12.018, 2010.

Koch, D., Bond, T. C., Streets, D., Unger, N., and Van der Werf, G. R.: Global impacts of aerosols from particular source regions and sectors, J. Geophys. Res., 112, D02205, doi:10.1029/2005JD007024, 2007.

Koren, I., Kaufman, Y. J., Washington, R., Todd, M. C., Rudich, Y., Vanderlei Martins, J., and Rosenfeld, D.: The Bodélé depression: a single spot in the Sahara that provides most of the mineral dust to the Amazon forest, Environ. Res. Lett., 1, 014005, doi:10.1088/1748-9326/1/1/014005, 2006.

Lavoué, D. and Stocks, B. J.: Emissions of air pollutants by Canadian wildfires from 2000 to 2004, International Journal of Wildland Fire, 20, 17-34, doi:10.1071/WF08114, 2011.

Lavoué, D., Liousse, C., Cachier, H., Stocks, B. J., and Goldammer, J. G.: Modeling of carbonaceous particles emitted by boreal and temperate wildfires at northern latitudes, J. Geophys. Res., 105,
26871-26890, 2000.

Lavoué, D., Gong, S. L., and Stocks, B. J.: Modelling emissions from Canadian wildfires: A case study of the 2002 Quebec forest fires, International Journal of Wildland Fire, 16, 649-663, doi:10.1071/WF06091, 2007.

Lewis, E. R. and Schwartz, S. E.: Sea salt aerosol production: mechanisms, methods, measurements, and models, American Geophysical Union, Washington, DC, 413 pp., 2004.

Liousse, C., Penner, J. E., Chuang, C., Walton, J. J., Eddleman, H., and Cachier, H.: A global three-dimensional model study of carbonaceous aerosols, J. Geophys. Res., 101, 19411-19432, 1996.

Liu, J., Mauzerall, D. L., and Horowitz, L. W.: Source-receptor relationships between East Asian sulfur dioxide emissions and Northern Hemisphere sulfate concentrations, Atmos. Chem. Phys., 8, 3721-3733, doi:10.5194/acp-8-3721-2008, 2008.

Marticorena, B. and Bergametti, G.: Modeling the atmospheric dust cycle. 1: Design of a soil-derived dust emission scheme, J. Geophys. Res., 100, 16415-16430, doi:10.1029/95JD00690, 1995.

Monahan, E. C., Spiel, D. E., and Davidson, K. L.: A model of marine aerosol generation via whitecaps and wave disruption, in: Oceanic whitecaps and their role in air-sea exchange processes, edited by: Monahan, E. C. and Mac Niocaill, G., D. Reidel, Norwell, Mass., 167-174, 1986.

O'Dowd, C. D. and Smith, M. H.: Physicochemical properties of aerosols over the northeast Atlantic: evidence for wind-speedrelated submicron sea-salt aerosol production, J. Geophys. Res., 98, 1137-1149, 1993.

Park, S. H., Gong, S. L., Zhao, T. L., Vet, R. J., Bouchet, V. S., Gong, W., Makar, P. A., Moran, M. D., Stroud, C., and Zhang, J.: Simulation of entrainment and transport of dust particles within North America in April 2001 ("Red Dust Episode"), Geophys. Res. Lett., 112, D20209, doi:10.1029/2007JD008443, 2007.

Penner, J. E., Andreae, M., Annegarn, H., Barrie, L., Feichter, J., Hegg, D., Jayaraman, A., Leaitch, R., Murphy, D., Nganga, J., and Pitari, G.: Aerosols, their direct and indirect effects, in: Climate Change 2001: The Scientific Basis, Report to Intergovernmental Panel on Climate Change from the Scientific Assessment Working Group (WGI), 289-416, edited by: Houghton, H. T., Ding, Y., Griggs, D. J., Noguer, M., van der Linden, P. J., Dai, X., Maskell, K., and Johnson, C. A., Cambridge University Press, 289-416, 2001.

Prospero, J. M. and Lamb, P. J.: African droughts and dust transport to the Caribbean: climate change implications, Science, 302, 1024-1027, doi:10.1126/science.1089915, 2003.

Reddy, M. S. and Boucher, O.: Climate impact of black carbon emitted from energy consumption in the world's regions, Geophys. Res. Lett., 34, L11802, doi:10.1029/2006GL028904, 2007.

Schultz, M. G.: On the use of ATSR fire count data to estimate the seasonal and interannual variability of vegetation fire emissions, Atmos. Chem. Phys., 2, 387-395, doi:10.5194/acp-2-387-2002, 2002.

Schulz, M., de Leeuw, G., and Balkanski, Y.: Sea-salt aerosol source functions and emissions, in: Emissions of atmospheric trace compounds, edited by: Granier, C., Artaxo, P., and Reeves, C. E., Kluwer Academic Publishers, Dordrecht, The Netherlands, 333-359, 2004.

Seiler, W. and Crutzen, P. J.: Estimates of gross and net fluxes of carbon between the biosphere and the atmosphere from biomass burning, Climatic Change, 2, 207-247, 
doi:10.1007/BF00137988, 1980.

Sharma, S., Lavoué, D., Cachier, H., Barrie, L. A., and Gong, S. L.: Long-term trends of the black carbon concentrations in the Canadian Arctic, J. Geophys. Res., 109, D15203, doi:10.1029/2003JD004331, 2004.

Stern, D. I.: Global sulfur emissions from 1850 to 2000, Chemosphere, 58, 163-175, 2005.

Stocks, B. J., Mason, J. A., Todd, J. B., Bosch, E. M., Wotton, B. M., Amiro, B. D., Flannigan, M. D., Hirsch, K. G., Logan, K. A., Martell, D. L., and Skinner, W. R.: Large forest fires in Canada, 1959-1997, J. Geophys. Res., 107, 8149, doi:10.1029/2001JD000484, 2003.

Sukhinin, A. I., French, H. F., Kasischke, E. S., Hewson, J. H., Soja, A. J., Csiszar, I. A., Hyer, E. J., Loboda, T., Conard, S. G., Romasko, V. I., Pavlichenko, E. A., Miskiv, S. I., and Slinkina, O. A.: AVHRR-based mapping of fires in Russia: New products for fire management and carbon cycle studies, Remote Sens. Environ., 93, 546-564, doi:10.1016/j.rse.2004.08.011, 2004a.

Sukhinin, A. I., French, N. H. F., Kasischke, E. S., Hewson, J. H., Soja, A. J., Csiszar, I. A., Hyer, E. J., Loboda, T., Conard, S. G., Romasko, V. I., Pavlichenko, E. A., Miskiv, S. I., and Slinkina, O. A.: Burned Areas in Russia, Department of Geography, University of Maryland, College Park, Maryland, 2004b.

Tansey, K., Grégoire, J.-M., Stroppiana, D., Sousa, A., Silva, J. M. N., Pereira, J. M. C., Boschetti, L., Maggi, M., Brivio, P. A., Fraser, R., Flasse, S., Ershov, D., Binaghi, E., Graetz, D., and Peduzzi, P.: Vegetation burning in the year 2000: Global burned area estimates from SPOT VEGETATION data, J. Geophys. Res., 109, D14S03, doi:10.1029/2003JD003598, 2004.

Tegen, I., Heinold, B., Todd, M., Helmert, J., Washington, R., and Dubovik, O.: Modelling soil dust aerosol in the Bodélé depression during the BoDEx campaign, Atmos. Chem. Phys., 6, 43454359, doi:10.5194/acp-6-4345-2006, 2006.

Textor, C., Schulz, M., Guibert, S., Kinne, S., Balkanski, Y., Bauer, S., Berntsen, T., Berglen, T., Boucher, O., Chin, M., Dentener, F., Diehl, T., Easter, R., Feichter, H., Fillmore, D., Ghan, S., Ginoux, P., Gong, S., Grini, A., Hendricks, J., Horowitz, L., Huang, P., Isaksen, I., Iversen, I., Kloster, S., Koch, D., Kirkevåg, A., Kristjansson, J. E., Krol, M., Lauer, A., Lamarque, J. F., Liu, X., Montanaro, V., Myhre, G., Penner, J., Pitari, G., Reddy, S., Seland, $\varnothing .$, Stier, P., Takemura, T., and Tie, X.: Analysis and quantification of the diversities of aerosol life cycles within AeroCom, Atmos. Chem. Phys., 6, 1777-1813, doi:10.5194/acp-6-1777-2006, 2006.
Todd, M. C., Martins, V., Washington, R., Lizcano, G., Dubovik, O., M'Bainayel, S., and Engelstaedter, S.: Mineral dust emission from the Bodele Depression, Chad during BoDEx 2005, J. Geophys. Res., 112, D06207, doi:10.1029/2006JD007170, 2007.

United Nations: The United Nations energy statistics database (2005), United Nations Statistics Division, New York, 5, 2007.

van der Werf, G. R., Randerson, J. T., Giglio, L., Collatz, G. J., Kasibhatla, P. S., and Arellano Jr., A. F.: Interannual variability in global biomass burning emissions from 1997 to 2004, Atmos. Chem. Phys., 6, 3423-3441, doi:10.5194/acp-6-3423-2006, 2006.

Venkatram, A., Karamchandani, P. K., and Misra, P. K.: Testing a comprehensive acid deposition model, Atmos. Environ., 22, 737-747, 1988.

Washington, R. and Todd, M. C.: Atmospheric controls on mineral dust emission from the Bodélé Depression, Chad: The role of the low level jet, Geophys. Res. Lett., 32, L17701, doi:10.1029/2005GL023597, 2005.

Wiedinmyer, C., Quayle, B., Geron, C., Belote, A., McKenzie, D., Zhang, X., O’Neill, S., and Wynne, K. K.: Estimating emissions from fires in North America for Air Quality Modeling, Atmos. Environ., 40, 3419-3432, 2006.

Zender, C. S., Miller, R. L., and Tegen, I.: Quantifying mineral dust mass budgets: Systematic terminology, constraints, and current estimates, Eos Trans. AGU, 85, 509, 2004.

Zhang, Q., Streets, D. G., Carmichael, G. R., He, K. B., Huo, H., Kannari, A., Klimont, Z., Park, I. S., Reddy, S., Fu, J. S., Chen, D., Duan, L., Lei, Y., Wang, L. T., and Yao, Z. L.: Asian emissions in 2006 for the NASA INTEX-B mission, Atmos. Chem. Phys., 9, 5131-5153, doi:10.5194/acp-9-5131-2009, 2009.

Zhao, T. L., Gong, S. L., Zhang, X. Y., Blanchet, J.-P., McKendry, I. G., and Zhou, Z. J.: A simulated climatology of Asian dust aerosol and its trans-Pacific transport. Part I: mean climate and validation, J. Climate, 19, 88-103, 2006.

Zhao, T. L., Gong, S. L., Zhang, X. Y., and Jaffe, D. A.: Asian dust storm influence on North American ambient PM levels: observational evidence and controlling factors, Atmos. Chem. Phys., 8, 2717-2728, doi:10.5194/acp-8-2717-2008, 2008.

Zhao, T. L., Gong, S. L., Huang, P., and Lavoué, D.: Hemispheric transport and influence of meteorology on global aerosol climatology, Atmos. Chem. Phys., 12, 7609-7624, doi:10.5194/acp12-7609-2012, 2012. 